\title{
Biomarker responses and accumulation of polycyclic aromatic hydrocarbons in Mytilus trossulus and Gammarus oceanicus during exposure to crude oil
}

\author{
Raisa Turja ${ }^{1} \cdot$ Steinar Sanni ${ }^{2,3} \cdot$ Milda Stankevičiūtè $^{4}$ - Laura Butrimavičienè ${ }^{4} \cdot$ Marie-Hélène Devier $^{5}$. \\ Hélène Budzinski $^{5} \cdot$ Kari K. Lehtonen $^{1}$
}

Received: 23 October 2019 / Accepted: 29 January 2020 / Published online: 20 February 2020

(C) The Author(s) 2020

\begin{abstract}
In the brackish water Baltic Sea, oil pollution is an ever-present and significant environmental threat mainly due to the continuously increasing volume of oil transport in the area. In this study, effects of exposure to crude oil on two common Baltic Sea species, the mussel Mytilus trossulus and the amphipod Gammarus oceanicus, were investigated. The species were exposed for various time periods (M. trossulus 4, 7, and 14 days, G. oceanicus 4 and 11 days) to three oil concentrations $(0.003,0.04$, and $0.30 \mathrm{mg} \mathrm{L}^{-1}$ based on water measurements, nominally aimed at $0.015,0.120$, and $0.750 \mathrm{mg} \mathrm{L}^{-1}$ ) obtained by mechanical dispersion (oil droplets). Biological effects of oil exposure were examined using a battery of biomarkers consisting of enzymes of the antioxidant defense system (ADS), lipid peroxidation, phase II detoxification (glutathione $S$-transferase), neurotoxicity (acetylcholinesterase inhibition), and geno- and cytotoxicity (micronuclei and other nuclear deformities). In mussels, the results on biomarker responses were examined in connection with data on the tissue accumulation of polycyclic aromatic hydrocarbons (PAH). In M. trossulus, during the first 4 days of exposure the accumulation of all PAHs in the two highest exposure concentrations was high and was thereafter reduced significantly. Significant increase in ADS responses was observed in M. trossulus at 4 and 7 days of exposure. At day 14, significantly elevated levels of geno- and cytotoxicity were detected in mussels. In G. oceanicus, the ADS responses followed a similar pattern to those recorded in M. trossulus at day 4; however, in G. oceanicus, the elevated ADS response was still maintained at day 11. Conclusively, the results obtained show marked biomarker responses in both study species under conceivable, environmentally realistic oil-in-seawater concentrations during an oil spill, and in mussels, they are related to the observed tissue accumulation of oil-derived compounds.
\end{abstract}

Keywords Bioaccumulation · Biomarkers $\cdot$ Crude oil $\cdot$ Gammarids $\cdot$ Mussels $\cdot$ Polycyclic aromatic hydrocarbons

Responsible Editor: Philipp Gariguess

Raisa Turja

raisa.turja@ymparisto.fi

1 Marine Research Centre, Finnish Environment Institute, Agnes Sjöbergin katu 2, FI-00790 Helsinki, Finland

2 NORCE - Norwegian Research Centre, Mekjarvik 12, N-4072 Randaberg, Norway

3 Faculty of Science and Technology, Department of Mathematics and Natural Science, University of Stavanger,

N-4036 Stavanger, Norway

4 Nature Research Centre, Institute of Ecology, Akademijos str. 2, LT-08412 Vilnius, Lithuania

5 Laboratory of Physico- and Toxico-Chemistry of the Environment (LPTC), University Bordeaux 1, Oceanic and Continental Environments and Paleoenvironments (EPOC, UMR 5805 CNRS), 351 cours de la Libération, F-33405 Talence, France

\section{Introduction}

Oil pollution continues to be a significant marine environmental threat. In the Baltic Sea, the occurrence of a major oil spill is considered to cause widespread damage to the local ecosystem. The specific characteristics of the Baltic Sea including semi-closedness with slow water exchange, a fragmented and shallow coastline, harsh winter conditions, and low biodiversity make it highly vulnerable to oil pollution (Rousi and Kankaanpää 2012). For example, in the Gulf of Finland, the annual transportation of crude oil and refined products is currently 160-170 million tonnes and the overall oil tanker traffic is constantly growing, thus increasing the risk of a major accident in the area (Hänninen and Rytkönen 2004; Lehikoinen et al. 2015). Preparedness for efficient response actions in case of a large oil spill includes good understanding of the potential 
biological effects of oil on local biota (Martínez-Gómez et al., 2010), which is also essential in the designing of effective preand post-spill monitoring strategies (Marigómez et al., 2013).

Crude oils transported along global shipping routes have a highly variable chemical composition and consist of thousands of different compounds influencing its environmental fate and toxicity (NRC 2003). Polycyclic aromatic hydrocarbons (PAHs) represent a highly toxic group of compounds that are readily taken up by marine organisms directly from the water through body surfaces or gills, or through the diet, inducing acute and long-term toxic effects (Hylland 2006; Martinez-Gomez et al. 2010). In addition to parent PAH compounds, crude oils contain other hydrocarbons such as thiophenes (sulfur-containing analogues of PAHs) and alkylaromatic compounds such as methylphenanthrenes and methylnaphthalenes (Neff et al. 2011; Pampanin and Sydnes 2013). These compounds have shown geno- and cytotoxic potential in human liver cells (Amat et al. 2004), and, although not widely studied, have been shown to bioaccumulate efficiently and to elicit sublethal effects also in marine organisms (Kropp and Fedorak 1998; Booth et al. 2007; Rowland et al. 2001)

During the last decades, the approach of determining actual biological effects of contaminants on biota by using various types of biomarkers has been widely elaborated and applied both in laboratory and field studies (van Der Oost 2003; Garmendia et al. 2011); Vethaak et al. 2017; Sanni et al. 2017; Beyer et al. 2017). Post-accident monitoring campaigns in relation to marine oil spill disasters such as "Exxon Valdez" (Alaska, USA) in 1989 and "Prestige" (Galicia, Spain) 2002 still showed detectable biological effects in organisms after several years from the accidents when tissue accumulation of hydrocarbons could not be observed anymore (Esler et al. 2010). In the Baltic Sea, biomarker studies on some key species have shown that many of them are sensitive to various pollutants commonly found in the marine environment, including compounds resulting from oil contamination (Baršienè et al. 2006a; Baršienè et al. 2012; Turja et al. 2013, 2014b; Lehtonen et al. 2016).

Apart from the well-known AhR receptor-mediated toxicity of PAHs, major threats to cellular integrity are generated by the increased production of reactive oxygen species (ROS) during the biotransformation processes, leading to an imbalanced redox state where ROS are not sufficiently neutralized by the antioxidant defense system (ADS) and cause damage to macromolecules such as lipids, proteins, and DNA (Baussant et al. 2009; Regoli and Giuliani 2014). Moreover, biotransformation of PAHs is known to produce highly reactive byproducts such as DNA-binding metabolites, resulting in geno- and cytotoxic effects (Le Dû-Lacoste et al. 2013). PAHs are known to induce the ADS and to cause oxidative damage in aquatic organisms through the production of ROS (Regoli and Giuliani 2014). Organisms use catalase (CAT), superoxide dismutase (SOD), glutathione reductase (GR), and glutathione peroxidase (GPx) as the main enzymatic antioxidants that provide cellular defense against endogenous and exogenous ROS. Membrane damage caused by ROS can be detected by measuring lipid peroxidation (LPO). Regarding detoxification of organic contaminants, the activity of glutathione $S$-transferase (GST), involved in phase II (conjugation), is a widely used biomarker in organisms exposed to PAHs (e.g., Kopecka et al. 2006; Richardson et al. 2008; Turja et al. 2014b). Exposure to oil compounds has shown to cause neurotoxic effects, e.g., inhibition of acetylcholinesterase (AChE) enzyme activity (Maisano et al. 2017). Moreover, severe geno- and cytotoxic effects have been reported in response to oil contamination, including the formation of micronuclei $(\mathrm{MN})$ and other nuclear deformities (Baršiene et al. 2012).

Selection of suitable organisms is an important step in the designing of biomonitoring programs. Mussels (especially of the genus Mytilus) and other bivalve molluscs are used extensively in biomonitoring to detect both the bioaccumulation of hydrocarbons and biological responses in relation to oil contamination (e.g., Cajaraville et al. 2000; Hylland et al. 2008; Turja et al. 2013). Their sessile, filter feeding lifestyle and generally low enzymatic degradation rates of organic contaminants render them capable of accumulating high levels of organic molecules, including PAHs. Crustacean amphipods, and especially species belonging to the genus Gammarus, are also considered as excellent bioindicator species since they are widespread over large salinity and habitat ranges (Whiteley et al. 2011) and respond to various types of environmental contamination including PAH pollution (e.g., Turja et al. 2014b).

Information on biological effects of crude oil in Baltic Sea species is scarce. The objective of the present study was to investigate the effects of exposure to crude oil on two Baltic Sea species, the mussel Mytilus trossulus and the amphipod Gammarus oceanicus, by applying the biomarker methods mentioned above. The species were exposed for various time periods to a range of oil concentrations obtained by mechanical dispersion. The results on biomarker responses were examined in connection with the PAH tissue accumulation data obtained during the experiments.

\section{Materials and methods}

The experimental animals were collected in September 2009 from two sites on the SW coast of Finland (Baltic Sea) where at $5 \mathrm{~m}$ depth the sea water salinity was 6.0 and temperature was $14{ }^{\circ} \mathrm{C}$. M. trossulus were collected by SCUBA diving in the coastal area of Hanko and G. oceanicus with hand nets from the outer archipelago (Granbusken skerry) near the Tvärminne Zoological Station of the University of Helsinki, 
considered to be a relatively clean area. The mussels were gently cleaned to remove any sessile organisms growing on their shells. After collection, the organisms were transported within $48 \mathrm{~h}$ in aerated, thermo-insulated boxes filled with water from the collection site to the special NORCE facilities (formerly International Research Institute of Stavanger; IRIS), Norway, for the oil exposure experiments. The desired brackish water salinity of 6.0 (characteristic for the Baltic Sea in SW Finland) used in the experiment was obtained by mixing natural seawater of (salinity 32) with tap water (not containing chlorine). The seawater used during these experiments was directly pumped from the fjord at $78 \mathrm{~m}$ depth and was sand filtered before use in the laboratory. The animals were acclimatized for 7 days prior to the experiment in flow-through $350 \mathrm{~L}$ tanks. During this period, the mussels were fed every other day with algal cells (Instant Algae ${ }^{\circledR}$ ) and the amphipods with tiny pieces of shrimp meat. Sampling (day 0) for mussels and gammarids was carried out after the acclimatization period.

\section{Experimental design}

A continuous flow system was used to create a dispersion of crude oil (type Arctic Oil) in seawater. The oil was injected into seawater under pressure and passing through a valve to form small oil droplets (Sanni et al. 1998). Nominal concentration of injected oil, $5 \mathrm{mg} \mathrm{L}^{-1}\left(7 \mathrm{~L} \mathrm{~min}^{-1}\right.$ seawater and $0.042 \mu \mathrm{L} \mathrm{m^{-1 }}$ oil), was used to make the dilutions used in the exposure concentrations. Brackish seawater was constantly prepared in an open tank in order to remove chlorine. The $5 \mathrm{mg} \mathrm{L}^{-1}$ oil dispersion was pumped into four mixing glass flasks where it was diluted to the nominal concentrations of $0.015,0.120$, and $0.750 \mathrm{mg} \mathrm{L}^{-1}$ with brackish water (Table 1), hereafter named as experimental groups of low (Lo), medium (Med), and high (Hi) oil concentration. The dispersed oil was constantly pumped into the experimental system with adjusted flow rates (Watson Marlow 520S pump, Teflon tubes [Swagelok]) for each treatment. Water flow rate from the mixing bottles into the aquaria was adjusted to 700 $800 \mathrm{~mL} \mathrm{~min}{ }^{-1}$. The experiment was carried out in a temperature-adjusted hall with a constant temperature of $14^{\circ} \mathrm{C}$ and a 12:12-h daylight rhythm.

M. trossulus were exposed in four aquaria of $100 \mathrm{~L}$, one for each treatment concentration, for 4, 7, and 14 days. At the beginning of the experiment, a total of 250 adult mussels sized $2.5-3.0 \mathrm{~cm}$ were added to each aquarium. At each sampling time 50-70 mussels were randomly removed from each aquarium and, again, randomly divided for the different analyses. Adult $G$. oceanicus were exposed in seven replicate aquaria $(30 \mathrm{~L})$ per treatment concentration for four and 11 days. At the beginning of the experiment, $80 \mathrm{G}$. oceanicus individuals of $1-1.5 \mathrm{~cm}$ in length were placed in each aquarium. Five pooled samples of five individuals were removed from each aquarium
Table 1 Measured PAH compounds in batch of Arctic crude oil used in the exposures

\begin{tabular}{|c|c|}
\hline Compound & $\mu \mathrm{g} \mathrm{g}^{-1}$ oil (ppm) \\
\hline Naphthalene & 985 \\
\hline C1-naphthalene & 2694 \\
\hline C2-naphthalene & 4196 \\
\hline C3-naphthalene & 2834 \\
\hline Sum 2-ring PAHs & 10,709 \\
\hline Acenaphthylene & $\operatorname{mi} *<$ \\
\hline Acenaphthene & $\mathrm{mi}^{*}<$ \\
\hline Fluorene & 73 \\
\hline Phenanthrene & 170 \\
\hline Anthracene & $*<$ \\
\hline C1-Phen/Anthr & 275 \\
\hline C2-Phen/Anthr & 307 \\
\hline Sum 3-ring PAHs & 825 \\
\hline Dibenzothiophene & 25 \\
\hline C1-dibenzothiophene & 69 \\
\hline C2-dibenzothiophene & 70 \\
\hline Sum DBTs & 164 \\
\hline Fluoranthene & 6 \\
\hline Pyrene & 5 \\
\hline Benzo(a)anthracene & 3 \\
\hline Chrysene/triphenylene & 9 \\
\hline C1-chrysene & 21 \\
\hline C2-chrysene & 24 \\
\hline Sum 4-ring PAHs & 68 \\
\hline Benzo(b,j)fluoranthene & 4 \\
\hline Benzo(k)fluoranthene & $*<$ \\
\hline Benzo(a)pyrene & 2 \\
\hline Sum 5-ring PAHs & 6 \\
\hline Indeno(1,2,3-cd)pyrene & $*<$ \\
\hline Benzo(g,h,i)perylene & $*<$ \\
\hline Dibenzo(a,h)anthracene & $*<$ \\
\hline Sum 6-ring PAHs & 0 \\
\hline Total measured PAHs & 11,772 \\
\hline Percentage of oil wt. & $1.2 \%$ \\
\hline
\end{tabular}

mi $*<$ : matrix interference, $*<$ : below quantification limit

for analyses after 4 days and three pooled samples after 11 days of exposure. The bottom of the aquaria was cleaned every day and any dead individuals found were removed. The flow-through system was stopped once a week to clean the mixing bottles and oil tubes with hot tap water and rinsed with brackish water to avoid oil blocking the system. Animals were not fed during the experiment to avoid algal culture-related changes in clean water (controls) compared to the water with oil (oil exposure treatments) and thus result in difficult feeding-related differences between the treatments. Moreover, non-feeding was not expected to affect the results 
markedly due to the reason that Baltic Sea organisms have their energy reserves filled up at this time of the year being therefore naturally adapted to fasting occurring during the long winter period.

\section{Chemical analysis of hydrocarbons in water and in mussel tissues}

Water concentrations of 26 different PAH compounds were analyzed in the laboratory, based on a standard protocol (EPA 610) with previously described modifications (Jonsson et al. 2004). Water samples were collected weekly from the $5 \mathrm{mg} \mathrm{L}^{-1}$ solution (see more details from a parallel experiment by Ingvarsdóttir et al. 2012) and once from the exposure aquaria of M. trossulus. Limit of quantification (LOQ) was set to approximately $0.005 \mu \mathrm{g} \mathrm{L} \mathrm{L}^{-1}$ for each PAH component.

Analyses of PAH and other selected compounds in the tissues of mussels were carried out at the LPTC Université Bordeaux I using established protocols of the laboratory. Pooled samples consisting of whole soft tissue of 30 mussels were used for the analyses. The samples were freeze-dried (Edwards Super Modulyo freeze dryer) and pulverized with a grinding mortar. Extraction and quantification protocols for PAHs have been described elsewhere (Baumard et al. 1997). All steps of the analytical protocol were validated in terms of reproducibility and accuracy; procedural blanks were systematically checked and certified reference mussel tissue (1974a NIST) were analyzed together with the actual samples (Tapie et al. 2008; Thompson and Budzinski 2000). The obtained recoveries ranged between 70 and $20 \%$ with coefficient of variation $<20 \%$. The detection limits of individual compounds in mussel tissues were in the range $0.1-1.0 \mathrm{ng} \mathrm{g}^{-1}$ dry weight.

\section{Biomarker measurements}

Most of the biomarkers were analyzed only in M. trossulus. In G. oceanicus, the analyzed parameters included the ADS biomarkers and biotransformation phase II activity (GST).

\section{ADS, biotransformation phase II activity, and neurotoxicity}

Enzymatic activities of CAT, GR, GPx, and SOD as well as the level of LPO were measured for the ADS response. GST was measured for biotransformation phase II activity, and $\mathrm{AChE}$ was measured to assess neurotoxicity. For the enzymatic assays, digestive glands of mussels $(n=15)$ were homogenized in potassium phosphate buffer $(100 \mathrm{mM}, \mathrm{pH} 7.4)$ and gills $(n=15)$ in sodium phosphate buffer $(200 \mathrm{mM}, \mathrm{pH} 7.0)$ containing $0.1 \%$ Triton-X. Pooled samples of whole G. oceanicus individuals were homogenized in $50 \mathrm{mM}$ potassium phosphate buffer including $2 \mathrm{mM}$ EDTA ( $\mathrm{pH} 7.5$ ).

GST activity was estimated by measuring the formation rate of the conjugated substrate (chlorodinitrobenzene
[CNDB]-glutathione [GSH]) at $340 \mathrm{~nm}$ (Habig et al. 1974). Final concentrations of $1 \mathrm{mM}$ CNDB (Sigma 237329) and $1 \mathrm{mM}$ GSH (Sigma G6529) in potassium phosphate buffer $(100 \mathrm{mM}, \mathrm{pH} 7.0)$ were used in the reaction. CAT activity was measured as CAT mediated degradation of hydrogen peroxide $\left(\mathrm{H}_{2} \mathrm{O}_{2}\right)$ at $240 \mathrm{~nm}$ (Claiborne 1985). The reaction mixture contained $4.3 \mu \mathrm{M} \mathrm{H}_{2} \mathrm{O}_{2}$ (Fluka 95302) in potassium phosphate buffer (100 mM, pH 7.0). GR activity was measured indirectly as consumption of NADPH in the reduction of oxidized glutathione (GSSG) (Carlberg and Mannervik 1975). The reaction mixture contained 2 mM EDTA (Sigma E5134), $0.5 \mathrm{mM}$ GSSG (Sigma G4376), and 0.1 mM NADPH (Sigma N7505) in potassium phosphate buffer $(100 \mathrm{mM}$, $\mathrm{pH}$ 7.5). GPx activity was measured by the consumption of NADPH in a glutathione reductase-coupled enzyme assay according to the method described by Flohe and Gunzler (1984). The reaction mixture contained $20 \mathrm{mM} \mathrm{GSH}$ (Sigma G6529), $2 \mathrm{mM}$ NADPH (Sigma N7505), $10 \mathrm{U} \mathrm{mL}^{-1}$ GR (Sigma G3664), $6 \mathrm{mM} \mathrm{H}_{2} \mathrm{O}_{2}$ (Fluka 95302) in potassium phosphate buffer (100 mM, pH 7.5) with 2 mM EDTA (Sigma E5134), $1 \mathrm{mM}$ DTT (Sigma D9779), and $1 \mathrm{mM} \mathrm{NaN}_{3}$ (Sigma S2002). SOD activity was defined as the amount of enzyme required to inhibit the rate of reduction of cytochrome c by $50 \%$ and measured at $550 \mathrm{~nm}$ (Mccord and Fridovic, 1969). The reaction mixture contained $1 \mathrm{mM}$ EDTA (Sigma E5134), $0.1 \mathrm{M}$ $\mathrm{NaOH}, 4.7 \mathrm{mM}$ xanthine (Sigma X7375), 0.2 M cytochrome $c$ (Sigma), and $6.7 \mathrm{mU}$ xanthine oxidase (Sigma X1875) in sodium phosphate buffer $(50 \mathrm{mM}, \mathrm{pH} 7.8)$. SOD (Sigma S7531) dilutions from 0 to $1.5 \mathrm{U} \mathrm{mL}^{-1}$ were made to create the standard curve. Levels of LPO were measured as the generation of thiobarbituric acid reactive substances (TBARS) (Ohkawa et al. 1979). The reaction mixture contained $0.24 \mathrm{M}$ trichloroacetic acid (Riedel de Haën 33731), $60 \mathrm{mM}$ Tris- $\mathrm{HCl}$ with $0.1 \mathrm{mM}$ DTPA, and $16 \mathrm{mM}$ 2-thiobarbituric acid (Sigma T5500). The amount of TBARS was measured by reading absorbance at $535 \mathrm{~nm}$. Analyses of AChE activity were performed from gill samples as described in Bocquené and Galgani (1998) with modifications as in Leiniö and Lehtonen (2005). AChE activity values are expressed as equivalents of acetylthiocholine (ACTC) hydrolyzed (nmol ACTC $\min ^{-1} \mathrm{mg}$ protein ${ }^{-1}$ ), with $1 \Delta$ O.D. corresponding to the hydrolysis of $75 \mathrm{nmol}$ of ACTC.

All the enzymatic assays, LPO, and protein content (Bradford 1976) used for the calculation of specific enzymatic activities were measured in 96-well microplates using the TECAN Infinite 200 (TECAN) spectrophotometer with the Magellan software.

\section{Morphometric condition of $M$. trossulus}

Condition index was (CI) determined in mussels $(n=15)$ using the formula $\mathrm{CI}=$ (soft tissue dry weight $[\mathrm{mg}] /$ shell length $\left.[\mathrm{mm}]^{2}\right) \times 100$. The weight change in total dry soft 
tissue of mussels in the different treatments and time points was determined for a standard size individual of $30 \mathrm{~mm}$ shell length using the allometric regression $W=a L^{b}$, where $W=$ dry weight, $L=$ length, and $a$ and $b$ intercept and slope, respectively.

\section{Geno- and cytotoxicity biomarkers in M. trossulus}

Mussel gills were analyzed after 14 days of exposure for the selected geno- and cytotoxicity parameters including micronuclei (MN), nuclear buds (NB), binucleated cells (BN), and fragmented apoptotic cells (FA). MN are extranuclear bodies that contain damaged chromosome fragments and/or whole chromosomes that are not incorporated into the nucleus after cell division. Frequency of BN is an indicator of abnormal cell division due to the disturbed cytokinesis while FA indicates changes in the apoptotic rate since elimination of cytogenetic damage by the apoptosis is a key process occurring at different rates in organisms (Fernandez et al. 2011; Mičić et al. 2002). Preparation of slides and investigation of gill cells was carried out following the method described earlier (Baršienè et al. 2004, 2006b). The stained slides were analyzed under bright-field Olympus BX51 microscopes (Tokyo, Japan) using an immersion objective (1000×). Two thousand cells with intact cellular and nuclear membranes per mussel were evaluated using blind scoring. The frequency of the different nuclear abnormalities was expressed as the number of occurrences per 1000 cells scored. The formation of $\mathrm{MN}$ and NB were assessed as genotoxicity endpoints, and $\mathrm{FA}, \mathrm{BN}$ cells as cytotoxicity endpoints.

\section{Data integration and statistical analysis}

The integrated biomarker index (IBR; Beliaeff and Burgeot 2002) is a simple mathematical tool based on the standardization of the different biomarker values and finally summing up each two neighboring biomarkers. To compare all biomarkers with each other, IBR was calculated for three different biomarker arrangements. The final IBR value is the mean value of these three arrangements. Here, a modification of the method where the index values are given divided by the number of biomarkers included in the calculations (IBR/n; Broeg and Lehtonen 2006) was applied. In M. trossulus, seven biomarkers (CAT, GST, GR, SOD, and LPO measured in the digestive gland, $\mathrm{AChE}$ in gills, and $\mathrm{CI}$ ) were used to calculate the IBR for 4 and 14 days of exposure. Since LPO and CI were not measured at day 7, they were left out leaving five biomarkers for IBR calculation at that time point. GST and CAT measured in gills were left out, because including them twice would emphasize these responses too much in the index value. Geno- and cytotoxicity were measured only at day 14 and for that reason they were left out from the IBR making it clearer to study those responses separately from index value calculated mainly with enzymatic responses.

For G. oceanicus, all the five measured biomarkers CAT, GST, GPx, SOD, and LPO were included in the calculation of the IBR for 4 and 11 days of exposure.

All data were tested for the normality with the Kolmogorov-Smirnov test and homogeneity of variance with Bartlett's test. One-way ANOVA ( $F$ statistics) followed by Bonferroni corrected pairwise $t$ test were used for normally distributed data and Kruskal-Wallis for non-parametric data ( $H$ statistics). Program $\mathrm{R}$ was used to calculate the statistics.

\section{Results}

\section{General observations}

In mussels, byssal thread formation was markedly decreased in higher oil concentrations. This was quantified by visual inspection and gently touching the mussels during the cleaning of the aquaria. In the control and Lo treatments, $90-95 \%$ of the mussels were properly attached to the bottom with byssi, while at Med their share was $50 \%$ and at Hi only 5\% (data not shown). Mussels kept their valves open in all treatments and were apparently filtering the water actively. However, by visual inspection, the amount of produced feces was markedly smaller in the Hi treatment. Average mortality in the control aquarium was three individuals per day and in the oil-exposed aquariums five individuals per day. In amphipods, average mortality in each control aquarium was one individual per day and in the oil treatments two individuals per day per aquarium.

\section{PAHs in the exposure water}

Analysis of the oil used in the exposure showed that it contained $1.2 \%$ of PAHs analyzed as 26 PAH constituents (Table 1). This is comparable to approximate per cent content of $1.5 \%$ PAH in crude oil as calculated from Neff [2002]. Analysis of water concentrations of the 26 PAHs resulted in the detection of eight compounds (Table 2). PAH concentrations measured in the exposure treatments showed reasonably good agreement with the target dilution range of the prepared crude oil exposure stock solution, being $0.040,0.498$, and $3.555 \mu \mathrm{g} \mathrm{L}^{-1}$ in the Lo, Med, and Hi treatments, respectively (Table 2). The actual PAH concentrations based on dilution alone could thus have been expected to be 2-4 times higher than that measured in the treatments; however, in oil exposure experiments lower concentrations in the water phase are common due to the hydrophobic oil substances being attached to tubes, tank walls and even the test organisms (shells of mussel). On the other hand, PAHs loading onto these surfaces could be a secondary supplier, thus altering their levels into 
Table 2 Water concentrations $\left(\mu \mathrm{g} \mathrm{L}^{-1}\right)$ of selected PAHs detected in the prepared crude oil exposure stock solution (5 $\mathrm{mg} \mathrm{L}^{-1}$, three replicate measurements; from Ingvarsdóttir et al. 2012) and in the exposure aquaria after dilution to the desired exposure concentrations of Lo, Med, and Hi (one measurement, present study) in the flow-through exposure system

\begin{tabular}{lllll}
\hline & \multirow{2}{*}{ Crude oil stock solution } & \multicolumn{2}{l}{ Exposure concentrations of crude oil } \\
\cline { 3 - 5 } & $5 \mathrm{mg} \mathrm{L}^{-1}$ & Lo & Med & Hi \\
\hline Naphthalene & $3.9 \pm 1.4$ & 0.003 & 0.031 & 0.207 \\
C1-naphthalene & $11.6 \pm 4.2$ & 0.008 & 0.116 & 0.771 \\
C2-naphthalene & $17.7 \pm 5.8$ & 0.014 & 0.176 & 1.337 \\
C3-naphthalene & $13.1 \pm 4.2$ & 0.012 & 0.135 & 1.019 \\
Fluorene & $0.2 \pm 0.1$ & nd & 0.003 & 0.017 \\
Phenanthrene & $0.6 \pm 0.2$ & 0.002 & 0.009 & 0.045 \\
C1-phenanthrene/anthracene & $1.0 \pm 0.3$ & 0.001 & 0.012 & 0.074 \\
C2-phenanthrene/anthracene & $1.2 \pm 0.4$ & nd & 0.015 & 0.085 \\
EPAHs & $49.4 \pm 16.6$ & 0.040 & 0.498 & 3.555 \\
\hline
\end{tabular}

$n d$ not detected the seawater during the experiment (e.g., Giannapas et al. 2012). However, these issues are difficult to assess with precision. Under the assumption that $1.2 \%$ of the crude oil used were PAHs, an estimate of actual oil exposure concentration would correspondingly be approximately $0.003,0.04$, and $0.30 \mathrm{mg} \mathrm{L}^{-1}$.

C1-C3 naphthalenes occurred in up to two orders of magnitude higher concentrations compared to the other measured PAHs (fluorene, phenanthrene [PHE], and the C1- and C2PHE/anthracene sum parameter).

\section{PAHs in mussel tissues}

During the experiment, the exposed mussels showed tissue accumulation of most of the analyzed PAH compounds (Table 3). At the higher concentrations of Med and Hi, a clear time-dependent accumulation hydrocarbons was observed. However, similar tissue concentrations were observed in the control and Lo-treated mussels after 4 and 14 days of exposure. PAH concentration in the Lo treatment was very low, $0.04 \mu \mathrm{g} \mathrm{L}^{-1}$, which did not cause accumulation exceeding the observed background PAH level in tissues.

The PAHs measured in mussel tissues were divided into two groups, of which 18 PAHs $\left(\mathrm{PAH}_{18}\right)$ belong to the compounds commonly measured in environmental samples and the other consisting of methylated PAHs and thioarenes. Of the $\mathrm{PAH}_{18}$, the share of the three main compounds, PHE, fluoranthene (FLU), and pyrene (PYR) was in total 83 and $80 \%$ in the control mussels (4 and 14 days, respectively), 72 and $64 \%$ in the Med group, and 63 and $54 \%$ in the Hi group. Total concentrations of $\mathrm{PAH}_{18}$ after 4 and 14 days were 207.5 and $201.9 \mathrm{ng} \mathrm{g} \mathrm{dw}^{-1}$ in the control treatment, 265.0 and $346.0 \mathrm{ng} \mathrm{g} \mathrm{dw}^{-1}$ in the Med group, and 482.0 and $682.0 \mathrm{ng} \mathrm{g} \mathrm{dw}^{-1}$ in the Hi group, respectively. $\mathrm{PAH}$ concentrations did not change in the control during the duration of the exposure; therefore, the same concentration (207.5 $\mathrm{ng} \mathrm{g} \mathrm{dw}^{-1}$ ) was assumed to occur also at day 0 of the experiment to calculate accumulation rates for the two exposure periods (day 0 to day 4 and day 4 to day 14). In regard to the exposure concentrations, the accumulation of $\mathrm{PAH}_{18}$ between the start of the experiment (day 0) and day 4 was higher at both concentrations (14.3 and $68.5 \mathrm{ng} \mathrm{g} \mathrm{dw}^{-1}$, respectively) compared to the rate between day 4 and day 14 ( 8.2 and $20 \mathrm{ng} \mathrm{g} \mathrm{dw}^{-1}$ ). For the methylated compounds, the accumulation rates between day 0 and day 4 were 20.2 and $138 \mathrm{ng} \mathrm{g} \mathrm{dw}^{-1}$ and from day 4 to day 14 were 9.9 and $37.4 \mathrm{ng} \mathrm{g} \mathrm{dw}^{-1}$ in the Med and Hi, respectively. Although accumulation of PAHs continued throughout the exposure period, this comparison of daily total $\mathrm{PAH}$ accumulation rates calculated for day 4 and day 14 showed their ca. twofold and fourfold decline during this period in the Med and Hi exposure groups, respectively. At the same time, the share of HMW PAHs from the accumulated load is increased markedly especially in the Hi group being $71 \%$ at the end of the exposure (Table 3). Finally, examining the relationships of naphthalene (NAP) and PHE between their methylated forms in the different treatments and time points shows that the initial high ratio of the parent compound vs. the methylated form decreased rapidly during the exposure experiment (Table 3).

\section{Responses in M. trossulus}

\section{ADS, biotransformation, and neurotoxicity}

After 4 days of exposure, a significantly increased CAT activity in the digestive gland $\left(F_{3,56}=10.1\right)$ was observed in $\mathrm{Hi}$ treatment compared to the control treatment $(p<0.001)$ and in the Med treatment $(p<0.05)$ and the Hi treatment $(p<0.001)$ compared to the Lo treatment (Fig. 1). A significantly higher SOD activity $\left(F_{3,56}=4.0\right)$ was detected in the 0.120 and in Hi treatments compared to the control treatment $(p<0.05)$. In gills, CAT activity was significantly higher $\left(F_{3,35}=4.9\right)$ in the Med treatment compared to the 0.015 $(p<0.01)$ and Hi treatments $(p<0.02)$.

After 7 days of exposure, a significantly lower GST activity $\left(F_{3,56}=5.6\right)$ in the digestive gland was detected in the Med 
Table 3 Mytilus trossulus. PAH concentrations ( $\mathrm{ng}^{-1} \mathrm{~g}^{-1}$ dry weight) measured in soft tissues after exposure to mechanically dispersed oil at different concentrations Lo, Med, and $\mathrm{Hi}$ and time periods (4 and 14 days)

\begin{tabular}{|c|c|c|c|c|c|c|c|c|}
\hline & $\begin{array}{l}\text { CT } \\
4 \text { days }\end{array}$ & Lo & Med & $\mathrm{Hi}$ & $\begin{array}{l}\text { CT } \\
14 \text { days }\end{array}$ & Lo & Med & $\mathrm{Hi}$ \\
\hline \multicolumn{9}{|l|}{$\mathrm{PAH}_{18}$} \\
\hline Naphthalene & 4.80 & 0.70 & 6.30 & 12.10 & 5.10 & 5.70 & 1.90 & 7.30 \\
\hline Acenaphthylene & 0.50 & 0.30 & 0.20 & 0.50 & 0.20 & 0.20 & nd & 0.10 \\
\hline Acenaphtene & 0.60 & 0.20 & 0.40 & 0.70 & 0.30 & 0.30 & nd & 0.80 \\
\hline Fluorene & 1.50 & 1.30 & 2.10 & 7.60 & 1.60 & 1.60 & 3.40 & 7.80 \\
\hline Phenanthrene (PHE) & 69.30 & 69.50 & 85.50 & 145.10 & 82.60 & 75.40 & 98.90 & 177.10 \\
\hline Anthracene & 4.00 & 3.20 & 3.30 & 3.20 & 2.60 & 2.00 & 2.40 & 4.30 \\
\hline Fluoranthene (FLU) & 31.20 & 29.80 & 38.50 & 64.40 & 27.00 & 26.70 & 50.90 & 89.10 \\
\hline Pyrene (PYR) & 72.20 & 62.80 & 67.60 & 92.30 & 55.20 & 44.80 & 71.90 & 101.20 \\
\hline Benzo[a]anthracene & 5.60 & 5.50 & 8.60 & 17.80 & 5.20 & 3.70 & 11.30 & 26.40 \\
\hline Triphenylene+chrysene & 10.70 & 11.80 & 32.10 & 95.60 & 8.80 & 10.20 & 58.90 & 181.80 \\
\hline Benzo $[\mathrm{b}, \mathrm{j}, \mathrm{k}]$ fluoranthene & 2.70 & 4.70 & 9.50 & 20.10 & 6.90 & 7.00 & 21.20 & 39.80 \\
\hline Benzo[e]pyrene & 2.80 & 4.90 & 7.20 & 15.80 & 3.60 & 4.30 & 16.30 & 30.40 \\
\hline Benzo[a]pyrene & 0.40 & 0.40 & 0.70 & 1.90 & 0.60 & 0.70 & nd & 2.90 \\
\hline Perylene & 0.90 & 0.80 & 1.20 & 1.40 & 1.60 & 2.40 & 4.80 & 2.10 \\
\hline Indeno[1,2,3-cd]pyrene & nd & nd & nd & nd & nd & nd & nd & 2.70 \\
\hline Dibenz $[\mathrm{a}, \mathrm{c}+\mathrm{a}, \mathrm{h}] \mathrm{anthracene}$ & nd & nd & nd & nd & nd & nd & nd & 1.70 \\
\hline Benzo[g,h,i]perylene & 0.30 & 0.60 & 1.40 & 3.10 & 0.60 & 1.30 & 4.40 & 6.70 \\
\hline$\Sigma \mathrm{PAH}_{18}$ & 207.5 & 196.5 & 264.6 & 481.6 & 201.9 & 186.3 & 346.3 & 682.2 \\
\hline PHE, FLU and PYR\% & $83 \%$ & $82 \%$ & $72 \%$ & $63 \%$ & $82 \%$ & $79 \%$ & $64 \%$ & $54 \%$ \\
\hline LMW PAHs & 80.7 & 75.2 & 97.8 & 169.2 & 92.4 & 85.2 & 106.6 & 197.4 \\
\hline HMW PAHs & 126.8 & 121.3 & 166.8 & 312.4 & 109.5 & 101.1 & 239.7 & 484.8 \\
\hline LMW PAHs $\%$ & $39 \%$ & $38 \%$ & $37 \%$ & $35 \%$ & $46 \%$ & $46 \%$ & $31 \%$ & $29 \%$ \\
\hline HMW PAHs $\%$ & $61 \%$ & $62 \%$ & $63 \%$ & $65 \%$ & $54 \%$ & $54 \%$ & $69 \%$ & $71 \%$ \\
\hline \multicolumn{9}{|c|}{ Methylated PAHs and thioarenes } \\
\hline $\begin{array}{l}\text { Benzo[b]naphtho[2,1-d] } \\
\text { thiophene }\end{array}$ & 1.0 & 1.9 & 11.6 & 40.1 & 1.6 & 2.8 & 23.0 & 59.4 \\
\hline 2-Methylnaphthalene & 0.0 & 0.2 & 4.7 & 36.3 & 0.4 & 0.8 & 5.2 & 22.6 \\
\hline 1-Methylnaphthalene & 0.0 & 0.1 & 2.7 & 19.0 & 0.0 & 0.0 & 1.1 & 11.5 \\
\hline 2-Methylanthracene & 1.0 & 1.9 & 1.3 & 0.0 & 0.7 & 0.6 & 0.0 & 0.0 \\
\hline 3-Methylphenanthrene & 49.6 & 45.8 & 84.8 & 282.7 & 46.8 & 45.5 & 125.8 & 426.0 \\
\hline 9-Methylphenanthrene & 55.7 & 55.3 & 101.4 & 377.7 & 52.9 & 50.8 & 159.4 & 608.7 \\
\hline Dibenzothiophene (DBT) & 1.0 & 1.6 & 3.2 & 10.9 & 1.8 & 1.8 & 4.9 & 14.0 \\
\hline 4-Methyl-DBT & 2.6 & 2.6 & 6.7 & 26.4 & 3.0 & 3.3 & 12.0 & 43.3 \\
\hline 1-Methyl-DBT & 1.7 & 1.5 & 5.1 & 22.2 & 1.7 & 1.9 & 8.9 & 34.0 \\
\hline 3+2-Methyl-DBT & 0.7 & 0.8 & 1.4 & 6.4 & 0.7 & 0.4 & 3.2 & 11.5 \\
\hline Emethylnaphthalenes & 0.0 & 0.3 & 7.4 & 55.3 & 0.4 & 0.8 & 6.3 & 34.1 \\
\hline इmethylphenanthrenes & 105.3 & 101.1 & 186.2 & 660.4 & 99.7 & 96.3 & 285.2 & 1034.7 \\
\hline ¿Methyl-DBTs & 5.0 & 4.9 & 13.2 & 55.0 & 5.4 & 5.6 & 24.1 & 88.8 \\
\hline ¿PAH & 320.8 & 308.2 & 487.5 & 1303.3 & 311.5 & 294.2 & 689.8 & 1913.2 \\
\hline $\mathrm{PAH}_{18} \%$ of $\Sigma \mathrm{PAH}$ & $64.7 \%$ & $63.8 \%$ & $54.3 \%$ & $37.0 \%$ & $64.8 \%$ & $63.3 \%$ & $50.2 \%$ & $35.7 \%$ \\
\hline $\begin{array}{l}\Sigma \text { Methylphenanthrenes \% } \\
\text { total PAH }\end{array}$ & $32.8 \%$ & $32.8 \%$ & $38.2 \%$ & $50.7 \%$ & $32.0 \%$ & $32.7 \%$ & $41.3 \%$ & $54.1 \%$ \\
\hline
\end{tabular}

$C T$ control treatment, $n d$ not detected treatment compared to control $(p<0.001)$ and in the Lo $(p=$ 0.03 ) group (Fig. 1). The activity of SOD was also significantly lower $\left(F_{3,56}=4.7\right)$ in the Med treatment compared to the $0.015(p=0.03)$ and Hi treatments $(p<0.01)$. In gills, the highest GST activity $\left(F_{3,36}=5.4\right)$ was detected in the Med group and it was significantly elevated compared to the Lo treatment ( $p=0.002)$ (Fig. 2). After 14 days, no significant enzymatic responses to oil exposure could be detected (Fig. 

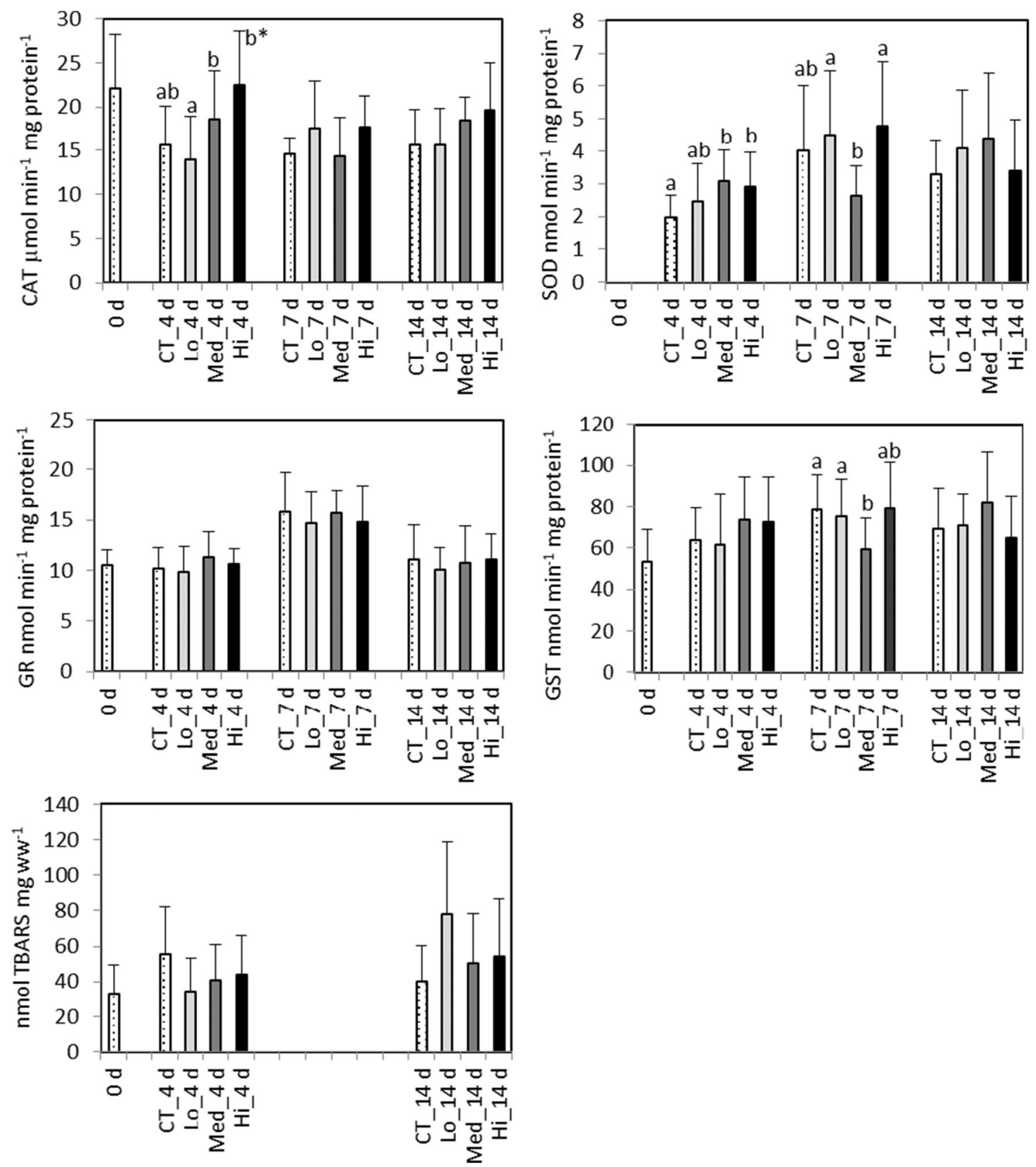

Fig. 1 Mytilus trossulus. Biomarkers responses measured in the digestive gland after a 4-, 7-, and 14-day exposure to control (CT) and different concentrations of dispersed crude oil (Lo, Med, and Hi). 0 d, sampled a day before the experiment started; GST, glutathione S-transferase; CAT,

2). Regarding both exposure time points, $\mathrm{AChE}$ activities (Fig. 2) and LPO levels (Fig. 1) did not show significant differences between treatments.

catalase; GR, glutathione reductase; SOD, superoxide dismutase; LPO, lipid peroxidation. Letters denote significant differences between the groups, mean $\pm \mathrm{SD}, n=15$, and asterisk denotes significant difference to control in CAT diagram

treatments; however, a decreasing trend was observed for both parameters at day 14 compared to day 4 (Fig. 3).

\section{Geno- and cytotoxicity}

\section{Morphometric body condition and weight change}

The morphometric condition index CI and the standardized soft tissue dry weight did not differ significantly between the

Analyses of geno- and cytotoxicity measured as chromosomal aberrations were made only on mussels at day 14 . No significant differences were found between the start and control group (data not shown). The Med and Hi 
Fig. 2 Mytilus trossulus. Biomarkers responses measured in the gills after a 4-, 7-, and 14day exposure to control (CT) and different concentrations of dispersed crude oil (Lo, Med, and Hi). $0 \mathrm{~d}$, sampled a day before the experiment started; GST, glutathione S-transferase; CAT, catalase; $\mathrm{AChE}$, acetylcholinesterase. Letters denote significant differences between the groups, mean \pm $\mathrm{SD}, n=10$
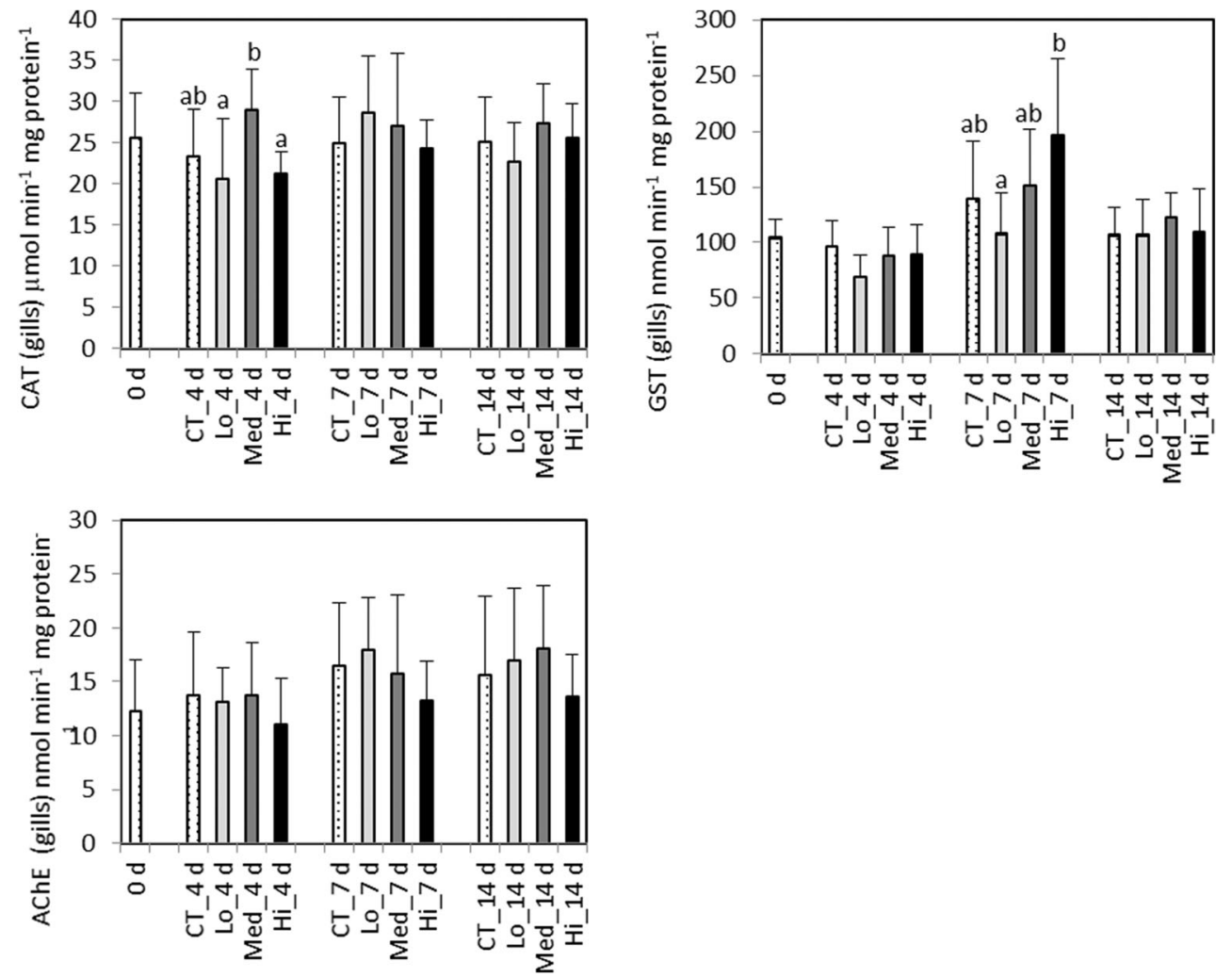

treatments induced significant formation of $\mathrm{MN}\left(F_{3.63}=\right.$ $12.77, p<0.0001)$ and $\mathrm{NB}\left(F_{3.63}=4.72, p=0.005\right)$ in gill cells compared to the control group $(p<0.01$ and $p<0.03$, for MN and NB, respectively). Treatments with Med and Hi induced a significant formation of FA $(H=32.46,3$ d.f., $p<0.001)$ cells in $M$. trossulus gill cells compared to the control group ( $p=0.007$ and $p<0.0007$, respectively). The frequency of BN $(H=11.17,3$ d.f., $p=0.011)$ cells showed the highest elevation in the Med treatment and the induced frequency was statistically significant $(p=0.01)$ compared to the control group. Frequencies of all the analyzed geno- and cytotoxicity endpoints did not show any significant changes in the lowest treatment group compared to control group (Fig. 4).

\section{Integrated biomarker response}

At day 4, the IBR index in M. trossulus was markedly elevated in the two highest concentrations (Fig. 5a). At day 7 , the response was highest in the Med treatment, when the Hi value was already decreased due to the typical bell-shaped response curves possessed by many of the enzymatic biomarkers used here (Fig. 5b). At day 14, the calculation of the IBR with the same battery of biomarkers proved unfeasible in mussels since no differences in these biomarker responses were observed at this time point. However, continuing effect of exposure was visible in geno- and cytotoxic markers showing significant responses at day 14 in the two highest concentrations (Fig. 4).
Fig. 3 Mytilus trossulus Morphometric condition index (CI) and dry weight (mg) of a "standard size" individual of $30 \mathrm{~mm}$ length measured at different time points of exposure to the control (CT) and different concentrations of dispersed crude oil (Lo, Med, and $\mathrm{Hi}$ ), mean $\pm \mathrm{SD}$, $n=15$
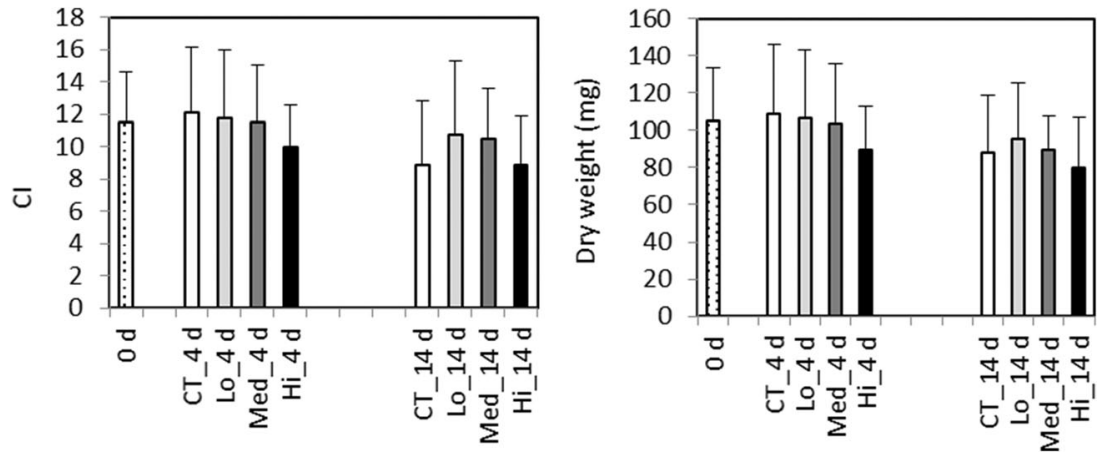
Fig. 4 Mytilus trossulus. Frequencies of genotoxicity and cytotoxicity endpoints (micronuclei [MN], nuclear buds [NB], fragmented apoptotic [FA], and binucleated $[\mathrm{BN}]$ cells) induced in gills after exposure to control (CT) and different concentrations of dispersed crude oil (Lo, Med, Hi) for a period of 14 days. Letters denote significant differences between the groups, mean $\pm \mathrm{SEM}, n=10$
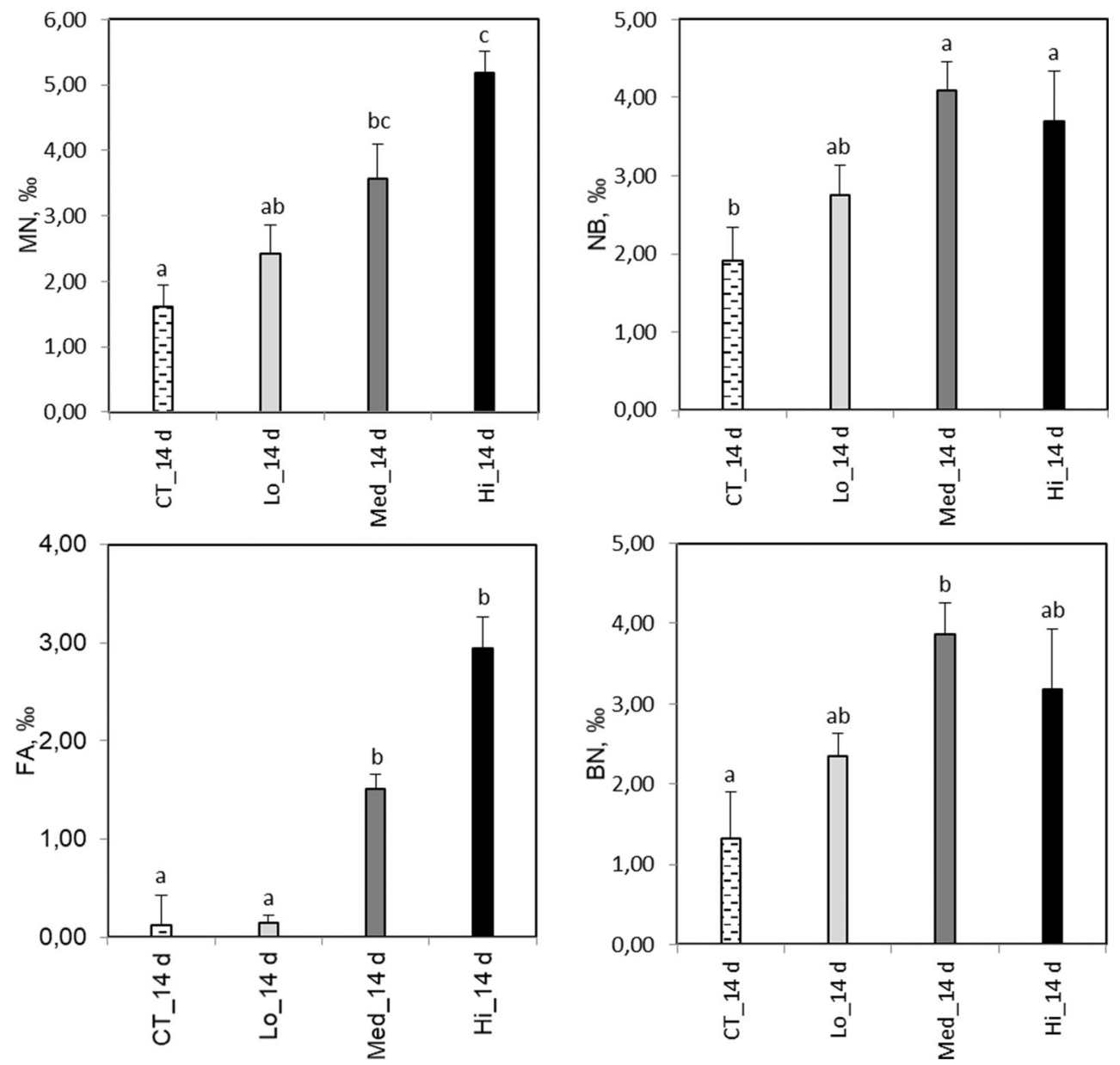

\section{Responses in G. oceanicus}

\section{ADS and biotransformation}

No statistical differences in the measured parameters could be detected between the replicate aquaria for each treatment and exposure time (data not shown); therefore, all the samples per treatment at each sampling point were used to calculate the final results.

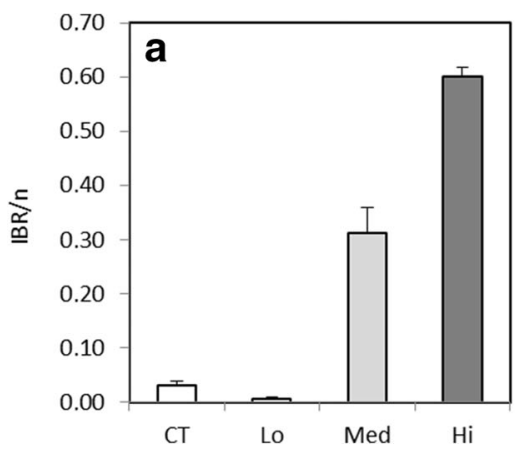

Fig. 5 Integrated biomarker index (IBR/n) in Mytilus trossulus after 4 days (a) and 7 days (b) of exposure to control (CT) and to different concentrations of dispersed crude oil (Lo, Med, and Hi). Seven biomarkers (GST, CAT, GR, SOD, and LPO in the digestive gland, AChE
After 4 days of exposure, the activities of GST and CAT were significantly elevated in the highest, Hi treatment compared to all the other treatments $\left(F_{3,73}=38.3, p<0.0001\right.$ and $F_{3,134}=18.3, p<0.0001$, respectively; Fig. 6$)$. The activity of GPx in the Lo and Hi treatments showed significantly higher activities compared to the control and exposure to the Med treatment $\left(F_{3,134}=34, p<0.0001\right)$. SOD activity was significantly decreased at Med compared to the other treatments $(H=19.6, \mathrm{df}=3, p=0.0002)$.

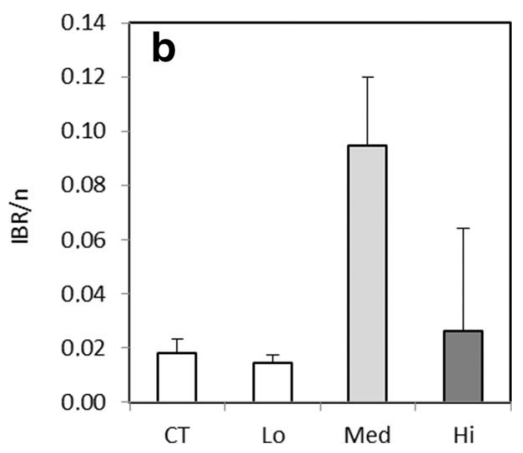

in gills, condition index) were used for day 4 and five biomarkers (GST, CAT, GR, and SOD in the digestive gland, AChE in gills) were used for day 7 IBR index. IBR result presented as mean \pm SD of three different biomarker arrangements 
Fig. 6 Gammarus oceanicus. Biomarkers responses after a 4 and 11-day exposure to control (CT) and different concentrations of dispersed crude oil (Lo, Med, and $\mathrm{Hi}$ ). $0 \mathrm{~d}$, sampled a day before the experiment started; GST, glutathione S-transferase; CAT, catalase; GPx, glutathione peroxidase; SOD, superoxide dismutase; LPO, lipid peroxidation. Letters denote significant differences between the groups, mean \pm $\mathrm{SD}, n=35$ at 4 days and $n=21$ at 11 days
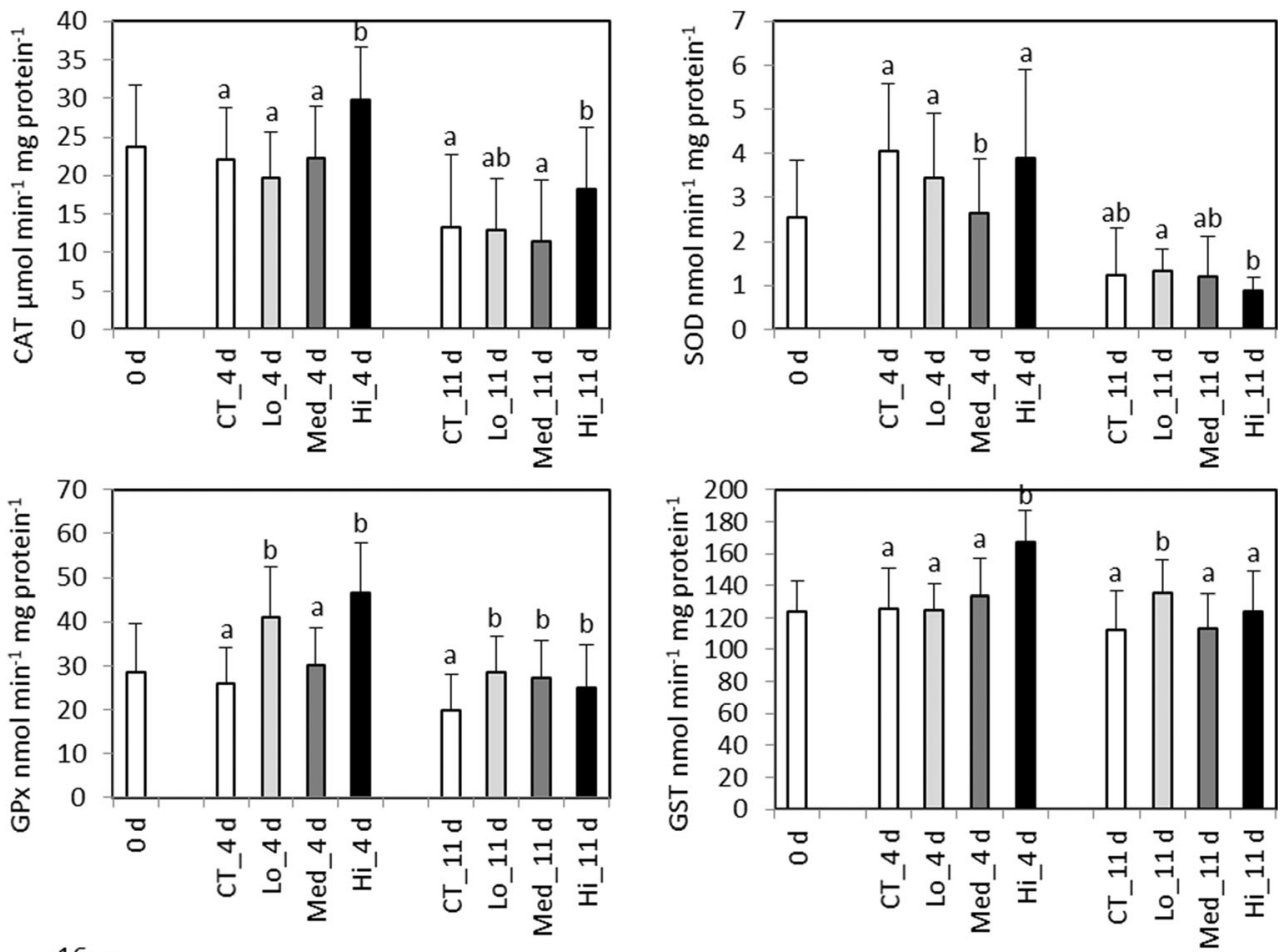

After 11 days' exposure time, the activity of GST in the Lo group was significantly elevated compared to the other treatments $\left(F_{3,76}=4.7, p=0.01\right.$; Fig. 6$)$. A higher CAT activity was observed in the Hi treatment compared to the control and the Med group $(H=13.5, \mathrm{df}=3, p=0.004)$. GPx activity was significantly higher in all treatments compared to the control group $\left(F_{3,76}=7.9, p<0.001\right)$. A significantly lower SOD activity was detected in gammarids exposed to Hi compared to $\operatorname{Lo}(H=10.1, \mathrm{df}=3, p=0.02)$.

\section{Integrated biomarker response}

On day 4 of exposure the IBR index in G. oceanicus was markedly higher at the $750 \mathrm{mg} \mathrm{L}^{-1}$ treatment compared to the other treatments (Fig. 7a). After 11 days of exposure, the highest response was still observed at the $750 \mathrm{mg} \mathrm{L}^{-1}$ treatment (Fig. 7b); however, it was declined due to the typical bell-shaped responses of the measured enzymes.

\section{Discussion}

In this study, mussels and gammarid amphipods were exposed to mechanically dispersed crude oil in a concentration range considered realistic in case of the occurrence of oil spill at sea (e.g., González et al. 2006). In both species, significant biological responses were observed, supported by the accumulation patterns of oil-derived hydrocarbons measured in mussels' tissues. The specific features and interconnections between the responses as well as their linkage to exposure concentrations, tissue accumulation of different groups of compounds, and length of exposure are discussed below.

\section{Mytilus trossulus}

The fitness and survival of organisms depend on the ability to initiate a successful stress response when challenged by exposure to damaging environmental factors. In the present study, the exposed mussels accumulated most of the measured PAHs 


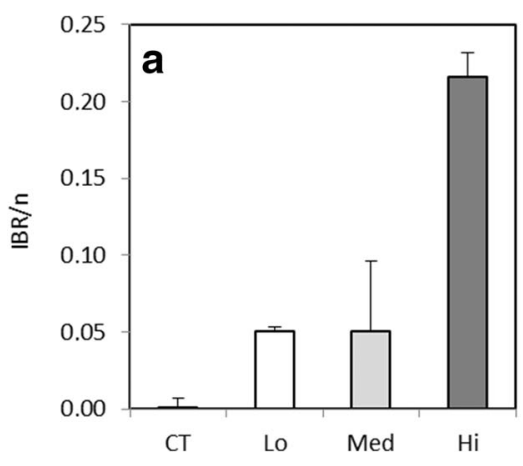

Fig. 7 Integrated biomarker index (IBR/n) in Gammarus oceanicus after 4 days (a) and 11 days (b) of exposure to control (CT) and to different concentrations dispersed crude oil (Lo, Med, and Hi). Five biomarkers

in a time- and concentration-dependent manner, except for those exposed to the lowest oil concentration of Lo, which did not show accumulation of PAHs nor significant biomarker responses compared to the control mussels. This observation is consistent with the parallel study by Ingvarsdóttir et al. (2012) on the effects of the same oil exposure arrangement using herring larvae. After 2 weeks in the highest exposure concentration of $\mathrm{Hi}$, the mussels accumulated up to $682 \mathrm{ng} \mathrm{g}^{-1} \mathrm{dw}$ of the $\mathrm{PAH}_{18}$ group and $1913 \mathrm{ng} \mathrm{g}^{-1} \mathrm{dw}$ of total PAHs. In field biomonitoring studies, the highest reported total PAH concentrations measured in mussel tissues after major oil spills range between > 1000 ("Sea Empress"), 6944 ("Erika"), and $7780 \mathrm{ng} \mathrm{g}^{-1} \mathrm{dw}$ ("Prestige") (Neuparth et al. 2012). A high accumulation in the two highest concentrations was expected since mussels are known to eliminate PAH very slowly from their tissues (e.g., Baussant et al. 2001).

Contaminant-induced ROS overproduction directs a strong antioxidant response to prevent oxidative stress (Regoli and Giuliani 2014). A rapid (during 1-7 days) activation of the ADS as a response to oil exposure and PAH contamination has been previously described in mussels (e.g., Grintzalis et al. 2012; Livingstone 2001; Luna-Acosta et al. 2011; Orbea and Cajaraville 2006), and also in gammarids (Hatlen et al. 2009; Turja et al. 2014b).

In the present study, in mussels, increased activities of CAT and SOD were observed at day 4 during exposure to the two highest oil concentrations. In mussels, CAT activity as well as the CAT gene transcription have been shown to be rapidly increased in response to PAH exposure; however, at higher exposure concentrations especially the enzyme activity can be inhibited (Giuliani et al. 2013). The observed increase of CAT and SOD activities in mussels is consistent with the relationship between their functions (Amstad et al. 1994). Since SOD catalyzes the dismutation of the superoxide radical into $\mathrm{H}_{2} \mathrm{O}_{2}$, which is then detoxified by CAT and/or the GPxGR cycle, an increase in SOD activity could be associated with an increase in $\mathrm{H}_{2} \mathrm{O}_{2}$ production resulting in elevated CAT activity. A positive correlation between SOD and CAT as well as positive correlation between SOD and individual

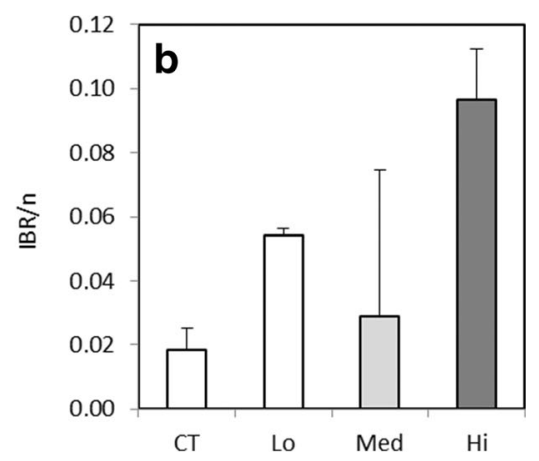

(GST, CAT, GPx, SOD, and LPO) were used to calculate IBR index for both time points, presented as mean $\pm \mathrm{SD}$ of three different biomarker arrangements

tissue PAHs and total PAHs has been previously reported in mussels exposed to PAHs (Richardson et al. 2008). The apparent non-response of GR suggests that under the exposure conditions the mussels were still coping with CAT as the main $\mathrm{H}_{2} \mathrm{O}_{2}$ degradation enzyme. Metabolism of certain PAH compounds produces reactive intermediates as well as ROS, connecting specific biotransformation processes to the degree of oxidative challenge (Baussant et al. 2009). In the present study, an elevated GST activity was detected in the gills tissues of mussels at day 7 in the highest exposure concentration of Hi. Similarly, Baussant et al. (2009) observed a significantly increased GST activity in Mytilus edulis exposed to mechanically dispersed North Sea crude oil. A marked increase in the GST activity in the gills of mussels after exposure to elutriates made from "Prestige" oil residues and oil-contaminated sediment was observed by Moreira et al. (2004), while mussels collected from oil-contaminated sites showed an increased GST activity even 1 year after the spill (Moreira et al. 2004; Tim-Tim et al. 2009).

In bivalves, the potential of PHE, PYR, and FLU to induce biological responses has been extensively reported (e.g., Grintzalis et al. 2012; Moore et al. 2007; Okay et al. 2006; Richardson et al. 2008; Yakan et al. 2013). In the present study, among the accumulated individual PAH compounds, the highest tissue concentrations were detected for methylphenanthrene, triphenyl+chrysene, PHE, PYR, and FLU. Examination of temporal accumulation dynamics of PAHs showed that both the $\mathrm{PAH}_{18}$ group and the methylated and thioarenes group showed a markedly higher rate between day 0 and day 4 compared to the exposure period from day 4 to day 14. At day 4 in the high concentration treatment of $\mathrm{Hi}$, a sixfold increase was observed in the tissue levels of 1- and 2methylphenanthrene (sum parameter); after day 14, the tissue levels were 1.6 times higher that recorded at day 4 . In bivalves, IBR index have been shown to provide indication of environmental stress caused by oil pollution (Luna-Acosta et al. 2017; Marigomez et al. 2013). In the present study, IBR index clearly showed the higher level of biological responses linked to rapid accumulation of PAHs during the first 
4 days of the exposure. Prolonged exposure time resulted typical bell-shaped response curves of the measured ADS parameters and lowered IBR index values.

At 14 days of exposure, all the measured ADS responses in M. trossulus were at same level in the oil-exposed and control groups; however, the increased ADS response detected at day 4 in the two highest oil concentrations suggests that the oxidative challenge may already then have contributed to the formation of the nuclear abnormalities observed at day 14 . Significantly elevated levels of geno- and cytotoxicity were detected in gill cells of mussels after exposure to Med and Hi concentrations. The potential of crude oil to cause geno- and cytotoxic effects for $M$. trossulus has been previously described in Baršienè and Andreikenaite (2007) showing significant $\mathrm{MN}$ induction in gill cells in mussels exposed to $0.05 \mathrm{mg} \mathrm{L}^{-1}$ crude oil. High levels of MN have been observed in M. edulis inhabiting sites heavily polluted by PAHs in the North Sea and in the Baltic Sea (Baršienè et al. 2004, 2006a). $\mathrm{MN}$ frequencies were significantly related to PAH concentrations measured in the mussel Perna from Guanabara Bay (Francioni et al. 2007). Increased levels of DNA damage have been detected in M. edulis and Atlantic cod (Gadus morhua) caged near to oil platforms in the North Sea (Hylland et al. 2008) as well as in M. galloprovincialis in the Adriatic Sea (Gorbi et al. 2008). A high incidence of MN after 4 and 14 days of exposure to petroleum water-soluble fraction was observed in peripheral erythrocytes of the mullet Mugil liza (Moreira et al. 2014). Significant long-term effects have been demonstrated in mussels showing elevated genotoxicity after 30 days post-oil spill (Parry et al. 1997) and cytogenetic damage lasting up to 6 months (Baršienè et al. 2012). Elevated levels of nuclear aberrations were also detected in the gills of M. trossulus caged at contaminated sites in the northern Baltic Sea (Turja et al. 2014a). Thus, the linkage of oil exposure to these geno- and cytotoxic lesions is well documented and the results frequently correlate with biomarkers related to the ADS overload (Brooks et al. 2011; Fernandez et al. 2011; Turja et al. 2014a), which leads to oxidative stress that is likely to cause macromolecular lesions, including DNA damage and subsequent chromosomal aberrations.

Examination of the tissue accumulation of PAH compounds at day 14 of the exposure showed increased share of HMW compounds compared to LMW fraction in mussel tissues in the two highest oil concentrations. This signifies a marked elevation in the accumulation of the assumedly more hazardous HMW PAHs during the exposure. Even though the uptake of LMW PAHs had practically halted at day 14 (generally observed, except for PHE), in the methylated forms it continued. It is unclear whether these changed tissue accumulation rates recorded at day 14 were due to a reduced uptake rate, activated metabolism, or depuration of the compounds. However, from a toxicological viewpoint these results are highly relevant. PHE, FLU, and PYR are by far the most commonly observed PAHs in surface waters and sediment of the Baltic Sea (Lang et al. 2015; Witt 2002) and regularly forming the majority of the background PAH levels in the tissues of mussels as well (Turja et al. 2012, 2014, 2015; Lehtonen et al. 2016). The marked decrease in the share of PHE, FLU, and PYR observed in the two highest oil treatments to the total of other $\mathrm{PAH}_{18}$ compounds in the tissues of mussel during the experiment clearly indicates exposure to oil, and this observation could also be useful in field studies and monitoring of oil pollution. Most of the HMW PAHs, which under exposure conditions are usually present in small quantities, show increased accumulation may be an ecologically relevant difference in case of an acute oil spill specifically in regard to the time of exposure and the onset of effects at different biological levels. Moreover, it has been recently discussed that alkylated PAHs should be more extensively studied in environmental samples since their toxic potential may easily surpass that of the parent compounds (Andersson and Achten 2015; Lam et al. 2018). For example, methylated phenanthrenes are generally recognized to be abundant among the PAHs of petrogenic origin, and they have been shown to activate the aryl hydrocarbon receptor (AhR) to induce transcriptional signaling more potently than does PHE (Sun et al. 2014). They have also been seen to be mutagenic and tumorinitiating (LaVoie et al. 1981). Thus, the investigations on the accumulation dynamics and toxicity of methylated PAHs in mussels can reveal important new information about the biological effects of oil exposure.

\section{Gammarus oceanicus}

In G. oceanicus, the activity of CAT and GPx were significantly increased at the highest Hi treatment at day 4 . Compared to ADS responses observed in mussels, the amphipod G. oceanicus needed to activate also the GSH pathway, most likely indicating a higher oxidative challenge caused by differences in behavioral aspects (active swimming vs. sessile mode and possibility of valve closure) and partly to the development of more severe starvation effects. In G. oceanicus, an increased CAT activity was previously shown in individuals exposed to $3 \mu \mathrm{g} \mathrm{L}^{-1}$ of B[a]P for 4 days (Turja et al. 2013). In the same study, GPx was increased in amphipods treated with $30 \mu \mathrm{g} \mathrm{L}{ }^{-1}$ of $\mathrm{B}[\mathrm{a}] \mathrm{P}$, suggesting that different $\mathrm{H}_{2} \mathrm{O}_{2}$ degrading pathways were activated depending on the exposure concentration. The inhibition of CAT activity under severe oxidative challenges is often partially compensated by the increased activity of the GSH pathway to remove excess $\mathrm{H}_{2} \mathrm{O}_{2}$ (Regoli et al. 2011). An increased GST activity was observed in the Hi treatment after 4 days of exposure compared to the other treatments. Significantly elevated GST activity has been previously reported in $G$. oceanicus exposed to $\mathrm{B}[\mathrm{a}] \mathrm{P}\left(3 \mu \mathrm{g} \mathrm{L}^{-1}\right)$ for 4 days (Turja et al. 2014b), suggesting that GST plays an important role in PAH metabolism in gammarids. Regarding 
other crustaceans, increased GST activity has been observed in green crabs (Carcinus maneas) exposed to FLU (16$100 \mu \mathrm{g} \mathrm{L}^{-1}$ ) for 7 days (Rodrigues et al. 2013). In the present study, the GST response in G. oceanicus did not differ from the control any more after 7 days of exposure. Excessive ROS formation may inhibit GST activation, and only after they have been eliminated by other enzymes (such as CAT or GPx), a significant elevation in GST activity can take place again (Fernandes et al. 2009; Kankaanpää et al. 2007; Turja et al. 2014b). Based on this assumption, the observed lack of the GST response in G. oceanicus in the present study could be explained by the excess ROS indicated by the elevated CAT and GPx activities after 11 days of exposure. Highest stress indicated by the IBR value was observed at 4 and 11 days of exposure to the highest oil concentration, while exposure to lower oil concentrations resulted in less clear differences.

\section{Conclusions}

Changing quantitative and qualitative dynamics were observed in the accumulation of PAH compounds in M. trossulus under a realistic oil concentration regime. In the present study, clearly elevated accumulation of all PAHs was detected during the first 4 days of exposure in the two highest exposure concentrations (Med and $\mathrm{Hi}$ ) and was thereafter reduced significantly with marked differences in the accumulation rates for different types of $\mathrm{PAH}$ compounds. In the tissue concentrations of the $\mathrm{PAH}_{18}$, the fraction of the highly toxic HMW compounds increased markedly during the experiment as well as the tissue levels of methylated forms of PHE elevated to constitute approximately $54 \%$ of the total tissue PAH load compared to the $35 \%$ prior to the exposure. Linked with the observed higher level of biological responses, it seems clear that the rapid accumulation of PAHs during the early phase of the exposure (first 4 days) induced many of the damage preventing mechanisms (such as ADS). During prolonged exposure (from 7 up to 14 days), the ADS system could not cope with the stress, seen as typically bell-shaped response curves in the measured parameters. Biomarker responses observed in $G$. oceanicus followed a similar pattern to those recorded in $M$. trossulus up to 4 days and in the Hi treatment they maintained the elevated ADS response still at day 11 . Overall, IBR index showed higher stress in exposed mussels (Med and Hi treatments) and gammarids (Hi treatment) than in the other treatments. Genotoxic and cytotoxic responses measured in mussels were present at 14 days indicating longer term effects of exposure. Moreover, toxicity of alkylated PAHs should be taken into consideration in future studies regarding oil contamination and biological effects.
Acknowledgments Open access funding provided by Finnish Environment Institute (SYKE). This work was supported by the Onni Talas Foundation. Facilities of Tvärminne Zoological Station were used when experimental animals were collected. Thank you to Anna Soirinsuo, Anna Nevala, Tanja Kinnunen, and Anna Korpela for the important assistance in animal collection and laboratory analysis. Thank you to Carina Björkblom for helping with the experimental set-up.

Authors' contribution RT, SS, and KL designed the study. RT build the experimental system with SS. RT, MS, and LB were responsible of the biological effects analysis and $\mathrm{M}-\mathrm{HD}$ and $\mathrm{HB}$ were responsible of the chemical analysis. All authors contributed to results and writing of the manuscript led by RT and KL.

Open Access This article is licensed under a Creative Commons Attribution 4.0 International License, which permits use, sharing, adaptation, distribution and reproduction in any medium or format, as long as you give appropriate credit to the original author(s) and the source, provide a link to the Creative Commons licence, and indicate if changes were made. The images or other third party material in this article are included in the article's Creative Commons licence, unless indicated otherwise in a credit line to the material. If material is not included in the article's Creative Commons licence and your intended use is not permitted by statutory regulation or exceeds the permitted use, you will need to obtain permission directly from the copyright holder. To view a copy of this licence, visit http://creativecommons.org/licenses/by/4.0/.

\section{References}

Amat A, Pfohl-Leszkowicz A, Castegnaro M (2004) Genotoxic activity of thiophenes on liver human cell line (HepG2). Polycycl Aromat Compd 24:733-742

Amstad P, Moret R, Cerutti P (1994) Glutathione peroxidase compensates for the hypersensitivity of $\mathrm{Cu}, \mathrm{Zn}$-superoxide dismutase overproducers to oxidant stress. J Biol Chem 269:1606-1609

Andersson J, Christine Achten C (2015) Time to say goodbye to the 16 EPA PAHs? Toward an up-to-date use of PACs for environmental purposes. Polycycl Aromat Compd 35(2-4):330-354

Baršienè J, Andreikenaite L (2007) Induction of micronuclei and other nuclear abnormalities in blue mussels exposed to crude oil from the North Sea. Ekologija 53:9-15

Baršienė J, Lazutka J, Syvokiene J, Dedonyte V, Rybakovas A, Bagdonas E, Bjornstad A, Andersen OK (2004) Analysis of micronuclei in blue mussels and fish from the Baltic and North Seas. Environ Toxicol 19:365-371

Baršienè J, Lehtonen KK, Koehler A, Broeg K, Vuorinen PJ, Lang T, Pempkowiak J, Syvokiene J, Dedonyte V, Rybakovas A, Repecka R, Vuontisjarvi H, Kopecka J (2006a) Biomarker responses in flounder (Platichthys flesus) and mussel (Mytilus edulis) in the KlaipedaButinge area (Baltic Sea). Mar Pollut Bull 53:422-436

Baršienè J, Schiedek D, Rybakovas A, Syvokiene J, Kopecka J, Forlin L (2006b) Cytogenetic and cytotoxic effects in gill cells of the blue mussel Mytilus spp. from different zones of the Baltic Sea. Mar Pollut Bull 53:469-478

Baršienė J, Rybakovas A, Garnaga G, Andreikenaite L (2012) Environmental genotoxicity and cytotoxicity studies in mussels before and after an oil spill at the marine oil terminal in the Baltic Sea. Environ Monit Assess 184:2067-2078

Baumard P, Budzinski H, Garrigues P (1997) Analytical procedure for the analysis of PAHs in biological tissues by gas chromatography 
coupled to mass spectrometry: application to mussels. Fresenius J Anal Chem 359:502-509

Baussant T, Sanni S, Jonsson G, Skadsheim A, Borseth JF (2001) Bioaccumulation of polycyclic aromatic compounds: 1 . Bioconcentration in two marine species and in semipermeable membrane devices during chronic exposure to dispersed crude oil. Environ Toxicol Chem 20:1175-1184

Baussant T, Bechmann RK, Taban IC, Larsen BK, Tandberg AH, Bjørnstad A, Torgrimsen S, Nævdal A, Øysæd KB, Jonsson G, Sanni S (2009) Enzymatic and cellular responses in relation to body burden of PAHs in bivalve molluscs: a case study with chronic levels of North Sea and Barents Sea dispersed oil. Mar Pollut Bull 58: 1796-1807

Beliaeff B, Burgeot T (2002) Integrated biomarker response: a useful tool for ecological risk assessment. Environ Toxicol Chem 21:13161322

Beyer J, Green NW, Brooks S, Allan IJ, Ruus A, Gomes T, Bråte ILN, Schøyen M (2017) Blue mussels (Mytilus edulis spp.) as sentinel organisms in coastal pollution monitoring: a review. Mar Environ Res 130:338-365

Bocquene G, Galgani F (1998) Biological effects of contaminants: cholinesterase inhibition by organophosphate and carbamate compounds. ICES Tech Mar Sci 22:12

Booth AM, Sutton PA, Lewis CA, Lewis AC, Scarlett A, Chau W, Rowland SJ (2007) Unresolved complex mixtures of aromatic hydrocarbons: thousands of overlooked persistent, bioaccumulative, and toxic contaminants in mussels. Environ Sci Technol 41(2): 457-464

Bradford M (1976) A rapid and sensitive method for the quantitation of microgram quantities of protein utilizing the principle of protein-dye binding. Anal Biochem 72:248-254

Broeg K, Lehtonen KK (2006) Indices for the assessment of environmental pollution of the Baltic Sea coasts: integrated assessment of a multi-biomarker approach. Mar Pollut Bull 53:508-522

Brooks S, Harman C, Zaldibar B, Izagirre U, Glette T, Marigomez I (2011) Integrated biomarker assessment of the effects exerted by treated produced water from an onshore natural gas processing plant in the North Sea on the mussel Mytilus edulis. Mar Pollut Bull 62: 327-339

Cajaraville MP, Bebianno MJ, Blasco J, Porte C, Sarasquete C, Viarengo A (2000) The use of biomarkers to assess the impact of pollution in coastal environments of the Iberian Peninsula: a practical approach. Sci Total Environ 247:295-311

Carlberg I, Mannervik B (1975) Purification and characterization of flavoenzyme glutathione reductase from rat-liver. J Biol Chem 250:5475-5480

Claiborne A (1985) Catalase activity. In: Greenwald RA (ed) Handbook of methods for oxygen radical research. CRC Press, Boca Raton, pp 283-284

Esler D, Trust KA, Ballachey BE, Iverson SA, Lewis TL, Rizzolo DJ, Mulcahy DM, Miles AK, Woodin BR, Stegeman JJ, Henderson JD, Wilson BW (2010) Cytochrome P4501A biomarker indication of oil exposure in harlequin ducks up to 20 years after the Exxon Valdez oil spill. Environ Toxicol Chem 29:1138-1145

Fernandes S, Welker M, Vasconcelos VM (2009) Changes in the GST activity of the mussel Mytilus galloprovincialis during exposure and depuration of microcystins. J Exp Zool A Ecol Genet Physiol 311A: 226-230

Fernandez B, Antonio Campillo J, Martinez-Gomez C, Benedicto J (2011) Micronuclei and other nuclear abnormalities in mussels (Mytilus galloprovincialis) as biomarkers of cyto-genotoxic pollution in Mediterranean waters. Environ Mol Mutagen 52:479-491

Flohe L, Gunzler WA (1984) Assays of glutathione-peroxidase. Meth Enzymol 105:114-121

Francioni E, Wagener ADLR, Scofield ADL, Depledge MH, Cavalier B, Sette CB, Carvalhosa L, Lozinsky C, Mariath R (2007) Polycyclic aromatic hydrocarbon in inter-tidal mussel Perna perna: space-time observations, source investigation and genotoxicity. Sci Total Environ 372:515-531

Garmendia L, Soto M, Ortiz-Zarragoitia M, Orbea A, Cajaraville MP, Marigomez I (2011) Application of a battery of biomarkers in mussel digestive gland to assess long-term effects of the Prestige oil spill in Galicia and Bay of Biscay: correlation and multivariate analysis. J Environ Monit 13:933-942

Giannapas M, Karnis L, Dailianis S (2012) Generation of free radicals in haemocytes of mussels after exposure to low molecular weight PAH components: immune activation, oxidative and genotoxic effects. Comp Biochem Physiol C 155:182-189

Giuliani ME, Benedetti M, Arukwe A, Regoli F (2013) Transcriptional and catalytic responses of antioxidant and biotransformation pathways in mussels, Mytilus galloprovincialis, exposed to chemical mixtures. Aquat Toxicol 134:120-127

González JJ, Viñas L, Franco MA, Fumega J, Soriano JA, Grueiro G, Muniategui S, López-Mahía P, Prada D, Bayona JM, Alzaga R, Albaigés J (2006) Spatial and temporal distribution of dissolved/ dispersed aromatic hydrocarbons in seawater in the area affected by the Prestige oil spill. Mar Pollut Bull 53:250-259

Gorbi S, Lamberti CV, Notti A, Benedetti M, Fattorini D, Moltedo G, Regoli F (2008) An ecotoxicological protocol with caged mussels, Mytilus galloprovincialis, for monitoring the impact of an offshore platform in the Adriatic Sea. Mar Environ Res 65

Grintzalis K, Georgiou CD, Dailianis S (2012) Total thiol redox status as a potent biomarker of PAH-mediated effects on mussels. Mar Environ Res 81:26-34

Habig WH, Pabst MJ, Jakoby WB (1974) Glutathione S-transferasesfirst enzymatic step in mercapturic acid formation. J Biol Chem 249: 7130-7139

Hänninen S, Rytkönen J (2004) Oil transportation and terminal development in the Gulf of Finland. VTT Technical Research Centre of Finland, Espoo

Hatlen K, Camus L, Berge J, Olsen GH, Baussant T (2009) Biological effects of water soluble fraction of crude oil on the Arctic Sea ice amphipod Gammarus wilkitzkii. Chem Ecol 25:151-162

Hylland K (2006) Polycyclic aromatic hydrocarbon (PAH) ecotoxicology in marine ecosystems. J Toxicol Environ Health Part A 69:109-123

Hylland K, Tollefsen K, Ruus A, Jonsson G, Sundt RC, Sanni S, Utvik TIR, Johnsen S, Nilssen I, Pinturier L, Balk L, Barsiene J, Marigomez I, Feist SW, Borseth JF (2008) Water column monitoring near oil installations in the North Sea 2001-2004. Mar Pollut Bull 56:414-429

Ingvarsdóttir A, Bjørkblom C, Ravagnan E, Godal BF, Arnberg M, Joachim DL, Sanni S (2012) Effects of different concentrations of crude oil on first feeding larvae of Atlantic herring (Clupea harengus). J Mar Syst 93:69-76

Jonsson G, Bechmann RK, Bamber SD, Baussant T (2004) Bioconcentration, biotransformation, and elimination of polycyclic aromatic hydrocarbons in sheepshead minnows (Cyprinodon variegatus) exposed to contaminated seawater. Environ Toxicol Chem 23(6): 1538-48

Kankaanpää H, Leinio S, Olin M, Sjövall O, Meriluoto J, Lehtonen KK (2007) Accumulation and depuration of cyanobacterial toxin nodularin and biomarker responses in the mussel Mytilus edulis. Chemosphere 68:1210-1217

Kopecka J, Lehtonen KK, Barsiene J, Broeg K, Vuorinen PJ, Gercken J, Pempkowiak J (2006) Measurements of biomarker levels in flounder (Platichthys flesus) and blue mussel (Mytilus trossulus) from the Gulf of Gdansk (southern Baltic). Mar Pollut Bull 53:406-421

Kropp KG, Fedorak PM (1998) A review of the occurrence, toxicity, and biodegradation of condensed thiophenes found in petroleum. Can J Microbiol 44(7):605-622

Lam MM, Bülow R, Engwall M, Giesy JP, Larsson M (2018) Methylated PACs are more potent than their parent compounds: a study of aryl 
hydrocarbon receptor-mediated activity, degradability, and mixture interactions in the H4IIE-luc assay. Environ Toxicol Chem 37: 1409-1419

Lang S, Hursthouse A, Mayer P, Kötke D, Hand I, Schulz-Bull D, Witt G (2015) Equilibrium passive sampling as a tool to study polycyclic aromatic hydrocarbons in Baltic Sea sediment pore-water systems. Mar Pollut Bull 101:296-303

LaVoie EJ, Tulley-Freiler L, Bedenko V, Hoffman D (1981) Mutagenicity, tumor-initiating activity, and metabolism of methylphenanthrenes. Cancer Res 41(9 Pt 1):3441-3447

Le Dû-Lacoste M, Akcha F, Dévier MH et al (2013) Comparative study of different exposure routes on the biotransformation and genotoxicity of PAHs in the flatfish species, Scophthalmus maximus. Environ Sci Pollut Res 20:690

Lehikoinen, A., M. Hänninen, , Storgård, J. E., Luoma, E., Mäntyniemi, S., Kuikka, S., 2015. A Bayesian network for assessing the collision induced risk of an oil accident in the Gulf of Finland. Environ Sci Technol. 49:5301-5309

Lehtonen KK, Turja R, Budzinski H, Devier M (2016) An integrated chemical-biological study using caged mussels (Mytilus trossulus) along a pollution gradient in the Archipelago Sea (SW Finland, Baltic Sea). Mar Environ Res 119:207-221

Leiniö S, Lehtonen KK (2005) Seasonal variability in biomarkers in the bivalves Mytilus edulis and Macoma balthica from the northern Baltic Sea. Comp Biochem Physiol C Toxicol Pharmacol 140: 408-421

Livingstone DR (2001) Contaminant-stimulated reactive oxygen species production and oxidative damage in aquatic organisms. Mar Pollut Bull 42:656-666

Luna-Acosta A, Kanan R, Le Floch S, Huet V, Pineau P, Bustamante P, Thomas-Guyon H (2011) Enhanced immunological and detoxification responses in Pacific oysters, Crassostrea gigas, exposed to chemically dispersed oil. Water Res 45:4103-4118

Luna-Acosta A, Bustamante P, Thomas-Guyon H, Zaldibar B, Izagirre U, Marigómez I (2017) Integrative biomarker assessment of the effects of chemically and mechanically dispersed crude oil in Pacific oysters, Crassostrea gigas. Sci Total Environ 598:713-721

Maisano M, Cappello T, Natalotto A, Vitale V, Parrino V, Giannetto A, Oliva S, Mancini G, Cappello S, Mauceri A, Fasulo S (2017) Effects of petrochemical contamination on caged marine mussels using a multi-biomarker approach: histological changes, neurotoxicity and hypoxic stress. Mar Environ Res 128:114-123

Marigomez I, Garmendia L, Soto M, Orbea A, Izagirre U, Cajaraville MP (2013) Marine ecosystem health status assessment through integrative biomarker indices: a comparative study after the Prestige oil spill "Mussel Watch". Ecotoxicology 22:486-505

Martinez-Gomez C, Vethaak AD, Hylland K, Burgeot T, Koehler A, Lyons BP, Thain J, Gubbins MJ, Davies IM (2010) A guide to toxicity assessment and monitoring effects at lower levels of biological organization following marine oil spills in European waters. ICES J Mar Sci 67:1105-1118

Mičić M, Bihari N, Jakšić Ž, Müller WEG, Batel R (2002) DNA damage and apoptosis in the mussel Mytilus galloprovincialis. Mar Environ Res 53:243-262

Moore MN, Viarengo A, Donkin P, Hawkins AJS (2007) Autophagic and lysosomal reactions to stress in the hepatopancreas of blue mussels. Aquat Toxicol 84:80-91

Moreira SM, Moreira-Santos M, Ribeiro R et al (2004) The 'Coral Bulker' fuel oil spill on the north coast of Portugal: spatial and temporal biomarker responses in Mytilus galloprovincialis. Ecotoxicology 13:619

Moreira CB, Rodrigues RV, Romano LA et al (2014) Genotoxicity and histological alterations in grey mullet Mugil liza exposed to petroleum water-soluble fraction (PWSF). Environ Sci Pollut Res 21: 5565
Neff JM (2002) Bioaccumulation in marine organisms. Effects of contaminants from oil well produced water. Elsevier Science Publishers, Amsterdam 452p

Neff J, Lee K, De Blois EM (2011) Produced water: overview of composition, fate, and effects. In: Lee K, Neff J (eds) Produced water. Environmental risks and advances in mitigation technologies. Springer, London

Neuparth T, Moreira SM, Santos MM, Reis-Henriques MA (2012) Review of oil and HNS accidental spills in Europe: identifying major environmental monitoring gaps and drawing priorities. Mar Pollut Bull 64:1085-1095

NRC (2003) Oil in the sea III: inputs, fates, and effects. National Academic Press, Washington, D.C.

Ohkawa H, Ohishi N, Yagi, K (1979) Assay for lipid peroxides in animal tissues by thiobarbituric acid reaction. Anal Biochem 95:351-358

Okay OS, Tolun L, Tufekci V, Telli-Karakoc F, Donkin P (2006) Effects of pyrene on mussels in different experimental conditions. Environ Int 32:538-544

Orbea A, Cajaraville MP (2006) Peroxisome proliferation and antioxidant enzymes in transplanted mussels of four Basque estuaries with different levels of poly cyclic aromatic hydrocarbon and polychlorinated biphenyl pollution. Environ Toxicol Chem 25: 1616-1626

Pampanin DM, Sydnes MO (2013) Polycyclic aromatic hydrocarbons a constituent of petroleum: presence and influence in the aquatic environment. IntertechOpen. https://doi.org/10.5772/48176

Parry JM, Harvey JS, Lyons BP (1997) O XIII.2 - O XIII.2 The application of genetic toxicology in the analysis of the consequences of a major marine pollution incident. Mutation Research/Fundamental and Molecular Mechanisms of Mutagenesis 379, S91

Regoli F, Giuliani ME (2014) Oxidative pathways of chemical toxicity and oxidative stress biomarkers in marine organisms. Mar Environ Res 93:106-117

Regoli F, Giuliani ME, Benedetti M, Arukwe A (2011) Molecular and biochemical biomarkers in environmental monitoring: a comparison of biotransformation and antioxidant defense systems in multiple tissues. Aquat Toxicol 105:56-66

Richardson BJ, Mak E, De Luca-Abbott SB, Martin M, McClellan K, Lam PK (2008) Antioxidant responses to polycyclic aromatic hydrocarbons and organochlorine pesticides in green-lipped mussels (Perna viridis): do mussels "integrate" biomarker responses? Mar Pollut Bull 57:503-514

Rodrigues AP, Lehtonen KK, Guilhermino L, Guimarães L (2013) Exposure of Carcinus maenas to waterborne fluoranthene: accumulation and multibiomarker responses. Sci Total Environ 443:454 463

Rousi H, Kankaanpää H (2012) The ecological effects of oil spills in the Baltic Sea - the national action plan of Finland, Environmental Administration Guidelines 6en| 2012, Finnish Environment Institute

Rowland S, Donkin P, Smith E, Wraige E (2001) Aromatic hydrocarbon "humps" in the marine environment: unrecognized toxins? Environ Sci Technol 35:2640-2644

Sanni S, Øysæd KB, Høivangli V, Gaudebert B (1998) A Continuous Flow System (CFS) for chronic exposure of aquatic organisms, Mar Environ Res 46:97-101

Sanni S, Lyng E, Pampanin DM, Smit M (2017) II Species sensitivity distributions based on biomarkers and whole organism responses for integrated impact and risk assessment criteria. Mar Environ Res 127: 11

Sun Y, Miller CA III, Wiese TE, Blake DA (2014) Methylated phenanthrenes are more potent than phenanthrene in a bioassay of human aryl hydrocarbon receptor (AhR) signaling. Environ Toxicol Chem 33:2363-2367

Tapie N, Budzinski H, Le Menach K (2008) Fast and efficient extraction methods for the analysis of polychlorinated biphenyls and 
polybrominated diphenyl ethers in biological matrices. Anal Bioanal Chem 391:2169-2177

Thompson S, Budzinski H (2000) Determination of polychlorinated biphenyls and chlorinated pesticides in environmental biological samples using focused microwave-assisted extraction. Int J Environ Anal Chem 76:49-60

Tim-Tim ALS, Morgado F, Moreira S, Rangel R, Nogueira AJA, Soares AMM, Guilhermino L (2009) Cholinesterase and glutathione Stransferase activities of three mollusc species from the NW Portuguese coast in relation to the 'Prestige' oil spill. Chemosphere 77:1465-1475

Turja R, Soirinsuo A, Budzinski H, Devier MH, Lehtonen KK (2013) Biomarker responses and accumulation of hazardous substances in mussels (Mytilus trossulus) transplanted along a pollution gradient close to an oil terminal in the Gulf of Finland (Baltic Sea). Comp Biochem Physiol C Toxicol Pharmacol 157:80-92

Turja R, Hoeher N, Snoeijs P, Barsiene J, Butrimaviciene L, Kuznetsova T, Kholodkevich SV, Devier M, Budzinski H, Lehtonen KK (2014a) A multibiomarker approach to the assessment of pollution impacts in two Baltic Sea coastal areas in Sweden using caged mussels (Mytilus trossulus). Sci Total Environ 473:398-409

Turja R, Guimaraes L, Nevala A, Kankaanpää H, Korpinen S, Lehtonen KK (2014b) Cumulative effects of exposure to cyanobacteria bloom extracts and benzo[a]pyrene on antioxidant defence biomarkers in Gammarus oceanicus (Crustacea: Amphipoda). Toxicon 78:68-77

Turja R, Lehtonen KK, Meierjohann A, Brozinski J, Vahtera E, Soirinsuo A, Sokolov A, Snoeijs P, Budzinski H, Devier M, Peluhet L,
Pääkkönen J, Viitasalo M, Kronberg L (2015) The mussel caging approach in assessing biological effects of wastewater treatment plant discharges in the Gulf of Finland (Baltic Sea). Mar Pollut Bull 97:135-149

van Der Oost R (2003) Fish bioaccumulation and biomarkers in environmental risk assessment: a review. Environ Toxicol Pharmacol 13: $57-149$

Vethaak AD, Davies IM, Thain JE, Gubbins MJ, Martínez-Gómez C, Robinson CD, Moffat CF, Burgeot T, Maes T, Wosniok W, Giltrap M, Lang T, Hylland K (2017) Integrated indicator framework and methodology for monitoring and assessment of hazardous substances and their effects in the marine environment. Mar Environ Res 124:11-20

Whiteley NM, Rastrick SPS, Lunt DH, Rock J (2011) Latitudinal variations in the physiology of marine gammarid amphipods. J Exp Mar Biol Ecol 400:70-77

Witt G (2002) Occurrence and transport of polycyclic aromatic hydrocarbons in the water bodies of the Baltic Sea. Mar Chem 79:49-66

Yakan SD, Henkelmann B, Schramm K, Okay OS (2013) Bioaccumulation-depuration kinetics and effects of phenanthrene on Mediterranean mussel (Mytilus galloprovincialis). J Environ Sci Health Part A 48:1037-1046

Publisher's note Springer Nature remains neutral with regard to jurisdictional claims in published maps and institutional affiliations. 